Research Article

\title{
Mechanisms of Floor Heave in Roadways Adjacent to a Goaf Caused by the Fracturing of a Competent Roof and Controlling Technology
}

\author{
Shuaigang Liu, ${ }^{1,2}$ Jianbiao Bai $\left(\mathbb{C}^{2}{ }^{2}\right.$ Xiangyu Wang, ${ }^{1}$ Bowen $W u,{ }^{1,2}$ and Wenda $W u^{1,2}$ \\ ${ }^{1}$ School of Mines, China University of Mining and Technology, Xuzhou 221116, China \\ ${ }^{2}$ State Key Laboratory of Coal Resources and Safe Mining, China University of Mining and Technology, Xuzhou 221116, China
}

Correspondence should be addressed to Jianbiao Bai; baijianbiao@cumt.edu.cn

Received 21 February 2020; Revised 30 April 2020; Accepted 4 May 2020; Published 19 May 2020

Academic Editor: Zhixiong Li

Copyright (C) 2020 Shuaigang Liu et al. This is an open access article distributed under the Creative Commons Attribution License, which permits unrestricted use, distribution, and reproduction in any medium, provided the original work is properly cited.

In traditional sequential single-wing mining practices, one-entry longwall mining systems make it challenging to efficiently and smoothly transfer mining equipment during a continuous mining sequence. In two-entry longwall systems, the headgate of the current panel and the tailgate of the next panel are excavated parallel to one another, effectively creating space for the transfer of mining equipment. The tailgate of the panel, however, is subjected to high-mining-induced stresses, causing severe floor heave, which seriously affects the efficiency of coal production. In this paper, field measurements and numerical simulation methods are used to reveal the mechanism of floor heave induced by the rupture and instability of a competent roof. The results show that the positional relationship between the adjacent tailgate and the longwall face is divided into three stages. Throughout the three stages, the area in which the coal pillar is not horizontally displaced moves from the center of the pillar to the goaf, and the area of peak vertical stress within the coal pillar shifts from the center of the pillar to the side nearest to the tailgate. Field studies suggest that the proposed technologies can effectively control floor heave in the tailgates of two-entry longwall mining systems.

\section{Introduction}

In one-entry longwall mining systems (see Figure 1(a)), the tailgate of the next longwall panel is generally excavated after the current panel has been mined out and the strata above the goaf have stabilized [1-3]. This causes significant interruptions and prevents continuous mining. As mining depth increases, ventilation challenges also become increasingly apparent [4]. In two-entry longwall systems (see Figure 1(b)), the tailgate of the next panel is excavated in advance, permitting continuous mining and solving challenges associated with transportation, ventilation, and gas control. However, the tailgate is inevitably subjected to mining-induced stresses as the current panel is mined, causing a series of problems, including an unstable coal pillar and the deformation and damage of the tailgate. A certain area of the tailgate in front of the working face is affected by the continuously moving front abutment pressure. The deformation of the roadway is generally unsubstantial (stage A). Within a certain range behind the goaf of the longwall face, the roadway is subjected to high mining-induced stresses caused by the fracture, turning, and slipping of the main roof, resulting in severe floor heave in the tailgate of the next panel (stages B and C) [5].

Many scholars have researched the movement and stability of the strata structures above tailgates located beside a goaf [6-8]. Jiang et al. [9] established a triangular suspended plate structure model to describe the strata at the end of a fully mechanized caving face. Li et al. [10] stated that the ground pressure characteristics in the tailgate are directly related to the geometrical dimensions and motion characteristics of the suspended plate structure. He [11] used the elastic foundation beam theory to prove that the lateral suspension structure will break above the coal seam, and the point of collapse will shift to deep position where the surrounding rock properties are higher. In recent decades, in 
order to effectively improve the recovery rate of coal resources and reduce the width of coal pillars, China has widely adopted narrow coal pillar road protection technology. Hou and $\mathrm{Li}$ [12] proposed the theory of large-small structures to describe the rocks surrounding the tailgate of fully mechanized longwall panels. The rock mass is defined as a large structure, and the rock bolts and anchored rock mass are defined as small structures. Studying and understanding the stability of a large number of narrow coal pillars along the tailgate are a prerequisite for large-scale overburden stabilization [13-18]. Ground control in tailgates driven along a goaf largely depends on maintaining the stability of the small structure as the large structure breaks and becomes unstable.

The roles played by the surrounding rock's horizontal stress, principal stress angle, and horizontal displacement leading to the breaking and instability of the strata overlying the goaf have also been examined. For example, considering the lateral fracture feature of the main roof above the goaf, Zhang [19] stated that the "three-hinge" structure of the main roof is subjected to extensive horizontal stresses during the fully mechanized mining process of the longwall face, causing severe disturbance in the coal pillar. Xu et al. [20] then proposed the concept of a neutral surface within the pillar, on which the horizontal displacement is zero, and suggested that the neutral surface be used as the base point for anchoring bolts. Liu et al. [21] carried out research on the principal stress magnitude and angle and the plastic zone distribution of coal pillars during the failure process of the overburden strata and obtained the axial principal stress distribution characteristics along seven sections of the tailgate. The principal stress characteristic curve is roughly symmetrical: the middle section is high and gentle, while the left and right sides are lower and more variable. The magnitude of the principal stress and the sharp change of the angle occurred in the lag influence stage. The principal stress is positively correlated with the extended range of the plastic zone. The principal stress angle determines the extended azimuth of the plastic zone. The plastic zone generates asymmetrical expansion under the joint action, causing asymmetric deformation of the adjacent roadway. Yang et al. [22] studied the horizontal displacement characteristics of the backfill in the key block retaining process during the spin-down process and calculated the friction between the roof, the backfill, and the caving gobs using the elastic foundation beam theory. Zhang [23] studied the relationship between the overlying strata's structural characteristics and the roof s asymmetric failure in the roadway along the goaf. He concluded that the high lateral bearing pressure will be generated directly on the roadway's roof following the patterns of the turning and sinking process of the broken block. This high pressure causes severe compression deformation within the coal pillars and finally leads to the asymmetrical distribution of stress along the roadway and along the rock surrounding the central axis of the roadway.

This paper is centered on a case study performed at the 15202 tailgate along the 15201 longwall face at Jingfu coal mine. A numerical simulation based on the case study was also carried out. The horizontal displacement and internal stress distribution characteristics within the coal pillar between the tailgate and the longwall face, the variation of the principal stress angle, and the floor heave mechanisms were evaluated based on field observations and numerical result. Supporting methods and parameters were proposed for controlling the floor heave in the tailgate.

\section{Case Study}

2.1. Geological and Mining Conditions. Jingfu coal mine is located in Shouyang City, Shanxi Province, China (Figure 2(a)). The main coal seam in the mine was the 15\# coal seam with an average thickness of $5.0 \mathrm{~m}$ and depth of $580 \mathrm{~m}$. The in situ vertical stress is approximately $14.5 \mathrm{MPa}$ in the coal seam. The coal seam was mined out using the fully mechanized longwall mining method with a two-entry layout. The headgate of the 15201 panel and the tailgate of the 15202 panel were excavated simultaneously along the coal seam floor. The width of the pillar between the two entries was $7.0 \mathrm{~m}$. The 15202 tailgate was rectangular with a height of $4.0 \mathrm{~m}$ and a width of $5.0 \mathrm{~m}$ (Figures 2(c) and 2(d)). The longwall face of the 15201 panel was $200 \mathrm{~m}$ wide and the length of the 15201 panel was $2000 \mathrm{~m}$ long. Rock layers above the coal seam consisted of limestone, sandy mudstone, fine sandstone, sandy mudstone, limestone, and medium sandstone in the ascending order, while the floor layers below the coal seam consisted of mudstone, sandy mudstone, medium sandstone, sandy mudstone, and mudstone in the descending order (Figure 2(b)). No unfavorable geological structures (faults or aquifers, etc.) were discovered in the study site.

\subsection{Deformation and Failure of the 15202 Tailgate}

2.2.1. Deformation. The 15202 tailgate was supported with rock bolts and cables. The roof support consisted of seven resin-grouted $2.4 \mathrm{~m}$ long, $22 \mathrm{~mm}$ in diameter rebar bolts spaced $0.8 \mathrm{~m}$ apart in a row. Cable bolts were also installed in the roof, with two cable bolts per row spaced $2.0 \mathrm{~m}$ apart. The cables were $8.3 \mathrm{~m}$ long and $18.9 \mathrm{~mm}$ in diameter. Each rib of the tailgate was reinforced by five resin-grouted $2.4 \mathrm{~m}$ long, $22 \mathrm{~mm}$ in diameter rebar bolts spaced $0.8 \mathrm{~m}$ apart in a row. Limited rock mass deformation occurred in the 15202 tailgate before the 15201 longwall face passed by. However, after the 15201 longwall face passed by, severe floor heave occurred in the 15202 tailgate.

In order to obtain the deformation and failure characteristics of the rock mass surrounding the tailgate under the influence of mining-induced stress, a monitored station was placed in the 15202 tailgate to monitor the convergence of the tailgate as the 15201 longwall panel approached and passed by the station (see Figure 2).

Figure 3 presents the monitoring results; from Figure 3, we can identify three stages in the deformation of the 15202 tailgate. When the 15201 longwall face was $10 \mathrm{~m}$ inby the monitoring station, the deformations of the two ribs, the roof, and the floor were only about $40 \mathrm{~mm}$; when the 15201 longwall face was $80 \mathrm{~m}$ outby, the floor have, roof sag, inward deformation of the solid coal rib, and inward 


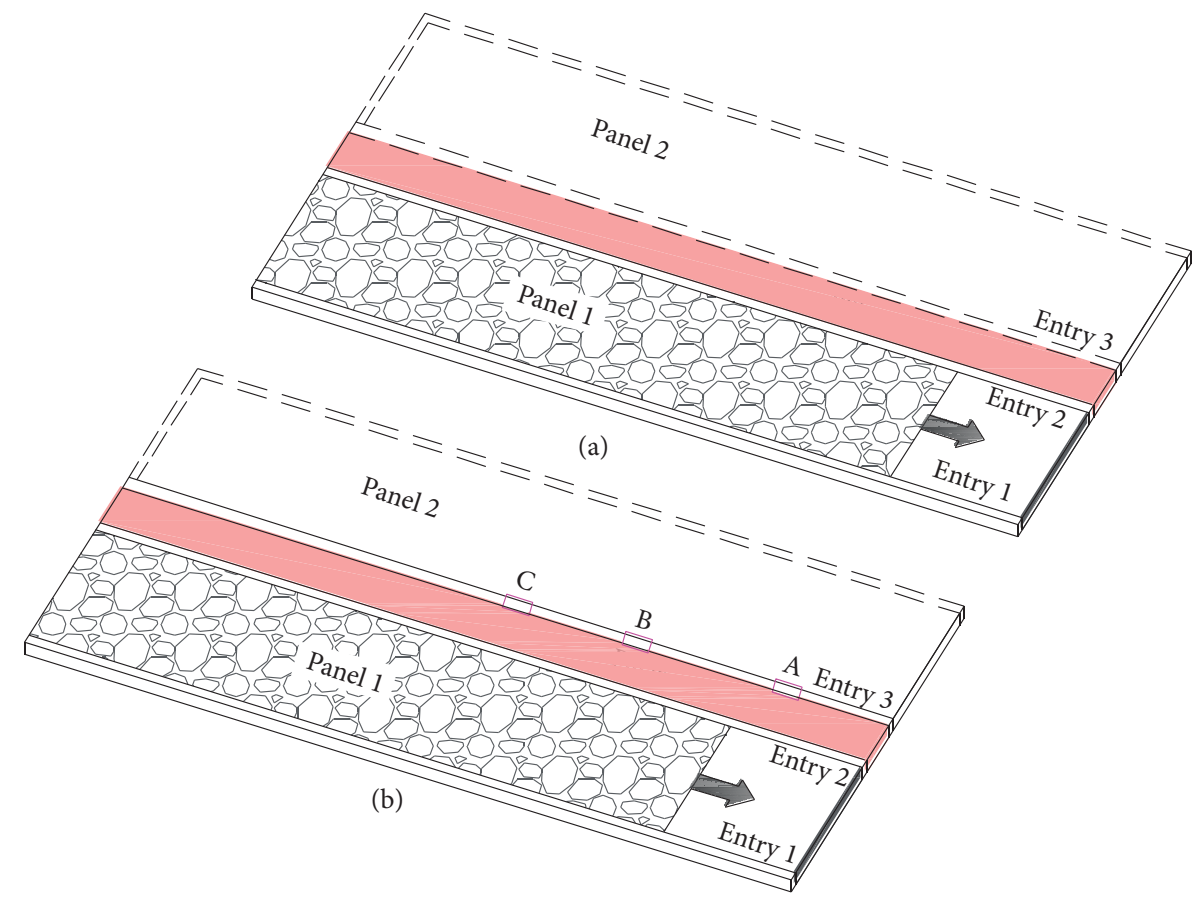

A: slow deformation
B: accelerating deformation
C: large deformation

FIGURE 1: Sketch of typical longwall panel layout. (a) Single-lane layout. (b) Double-lane layout.

deformation of the pillar rib reached up to $500,200,115$, and $350 \mathrm{~mm}$, respectively. When the 15201 longwall face was $150 \mathrm{~m}$ outby, the floor have, roof sag, inward deformation of the solid coal rib, and inward deformation of the pillar rib reached up to $1160,500,380$, and $770 \mathrm{~mm}$, respectively. The 15202 tailgate began to slowly deform when the 15201 longwall face was 10 inby, and two large deformations then occurred when the 15201 longwall face was $80 \mathrm{~m}$ and $150 \mathrm{~m}$ outby, respectively. The deformations of the pillar rib and the floor heave were significantly greater than the deformations of the solid coal rib and the roof sag, leading to the failure of the supporting materials. A large area of the 15202 tailgate suffered from high side abutment pressure caused during mining of the 15201 panel.

2.2.2. Pillar Stress. In order to obtain the progression of the stresses within the pillar under the impact of mining the 15201 longwall panel, borehole stress meters were installed in boreholes drilled horizontally into the pillar (Figure 2(e)). The boreholes were placed $30 \mathrm{~m}$ ahead of the 15201 longwall panel. The borehole stress meters were YHY60 (II) meters, with a measuring range of $0 \sim 60 \mathrm{MPa}$ and a precision of $1.0 \%$ full scale. The stress data obtained from the strain gauge was automatically recorded at 30-minute intervals, stored in the recording and monitoring device, and then transmitted to the infrared data transmission and acquisition device (Figure 4). The stress data was then transferred into software using an adaptor, which further communicated and processed the data for computer use.
It can be seen from Figure 5 that the stress distribution in the coal pillar differs substantially across the three stages of the 15202 tailgate's deformation. When the 15201 longwall face was $10 \mathrm{~m}$ inby, the vertical stress in the coal pillar was almost symmetrically distributed with a core at $x=3.5 \mathrm{~m}$, and the vertical stress in the middle of the coal pillar reached a peak value of 17.5 MPa. When the 15201 longwall face was $80 \mathrm{~m}$ outby the stress meters, the vertical stress in the middle of the coal pillar was $21.5 \mathrm{MPa}$, and the maximum vertical stress reached $24.0 \mathrm{MPa}$ at $x=4.5 \mathrm{~m}$. When the 15201 longwall face was $150 \mathrm{~m}$ outby the stress meters, the maximum vertical stress within the coal pillar reached $19.7 \mathrm{MPa}$ at $x=4.5 \mathrm{~m}$, while the stress in the middle of the coal pillar was 18.2 MPa. As the 15201 longwall face approached and passed by the stress meters, the maximum vertical stress within the coal pillar initially increased and then decreased, and the stress environment in the coal pillar gradually became asymmetrical. The location of the maximum vertical stress within the coal pillar moved away from the center of the pillar toward the 15201 goaf.

\subsubsection{Cracking Characteristic of the Competent Roof Strata.} The continuous, dynamic change of the overburden structure is the main source of side abutment pressure on the tailgate along a goaf. Therefore, a better understanding of the deformation and failure mechanism of a tailgate can come from analyzing the breaking and instability process of the competent roof strata. According to the proposed critical layer theory [24], the movement of the overburden on the 


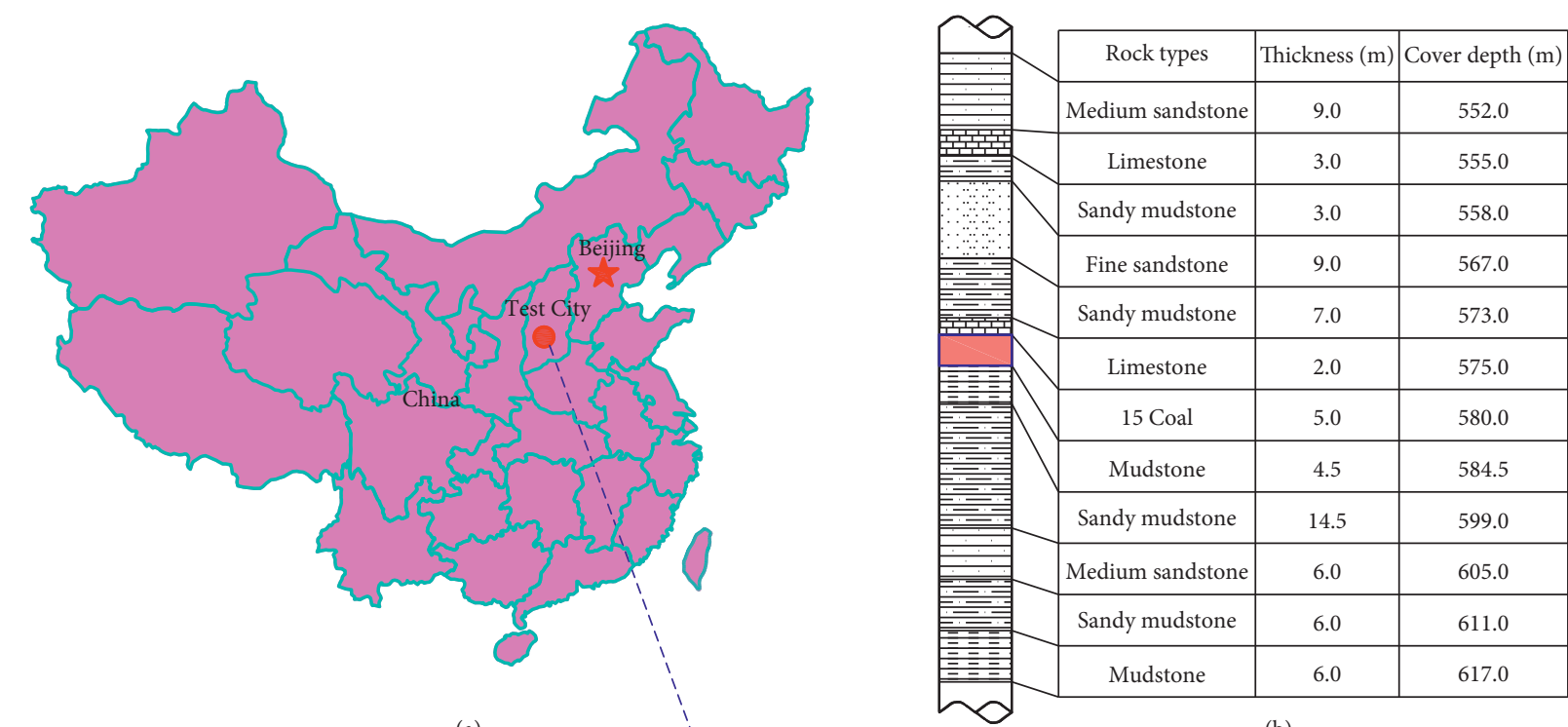

(a) $\quad \begin{aligned} & 1 \\ & 1\end{aligned}$

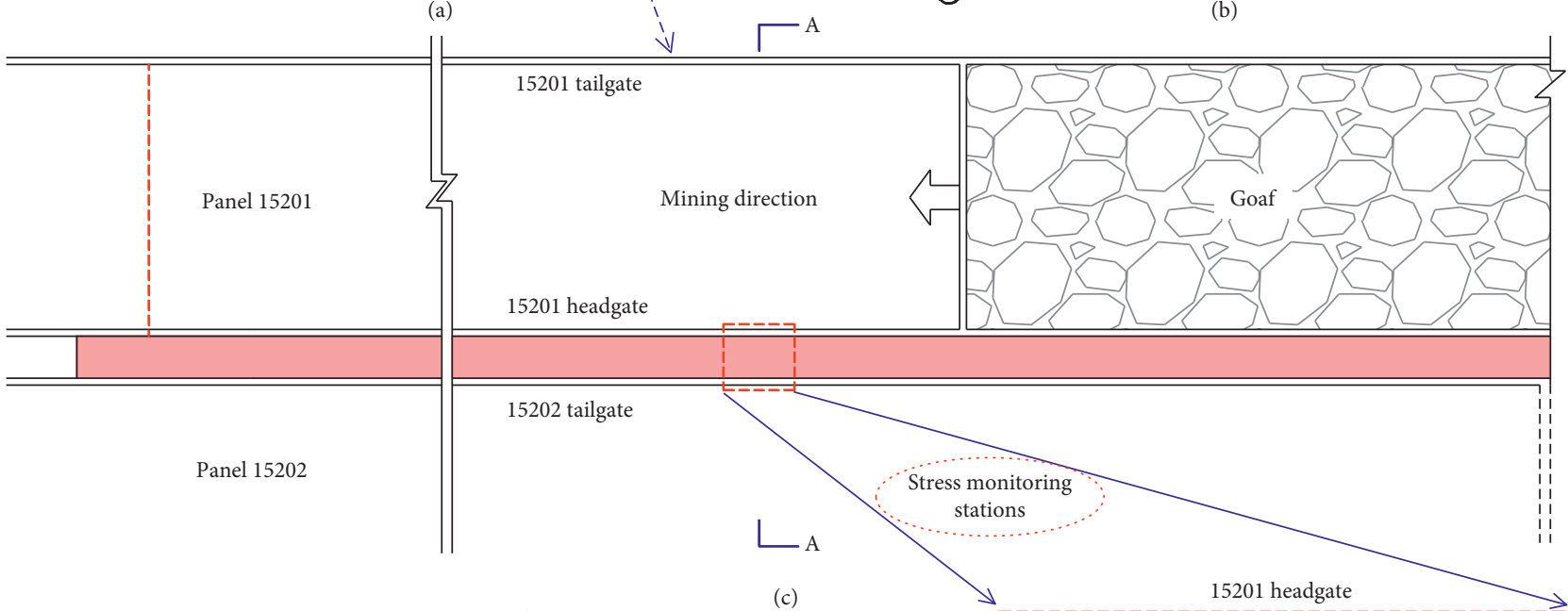

A-A

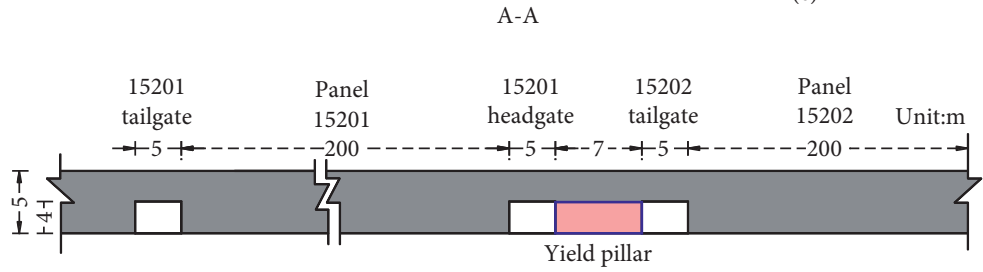

(d)

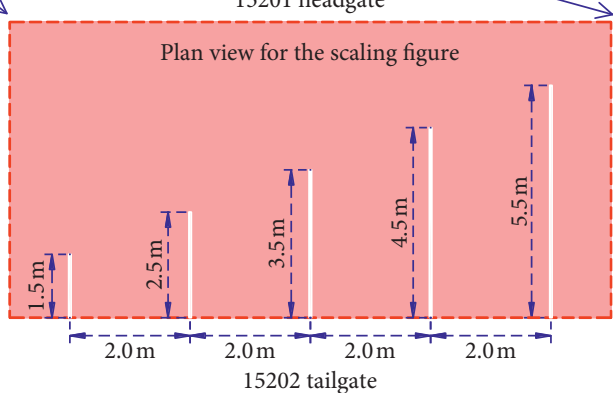

(e)

Figure 2: Mine location and panel layout of Jingfu coal mine.

longwall working surface is mainly controlled by several strong and thick key layers. When these critical layers rupture, all the weak layers above them will immediately fall and sink, which will have a major impact on the working space underneath. The geological conditions of the 15\# coal seams in Jingfu mine (Figure 1(b)) suggest that the sandstone mudstone layer with a thickness of $7 \mathrm{~m}$ is the closest critical layer affecting the 15201 longwall panel. Theoretically, as shown in Figure 3, as the longwall face advances forward, the area of suspended roof increases, and the direct bending moment gradually increases. The four-sided fixed top plate above the goaf breaks along its long side I first, because the bending moment here reaches its tensile strength limit first. This is followed by cracking along the short side II, leading to 


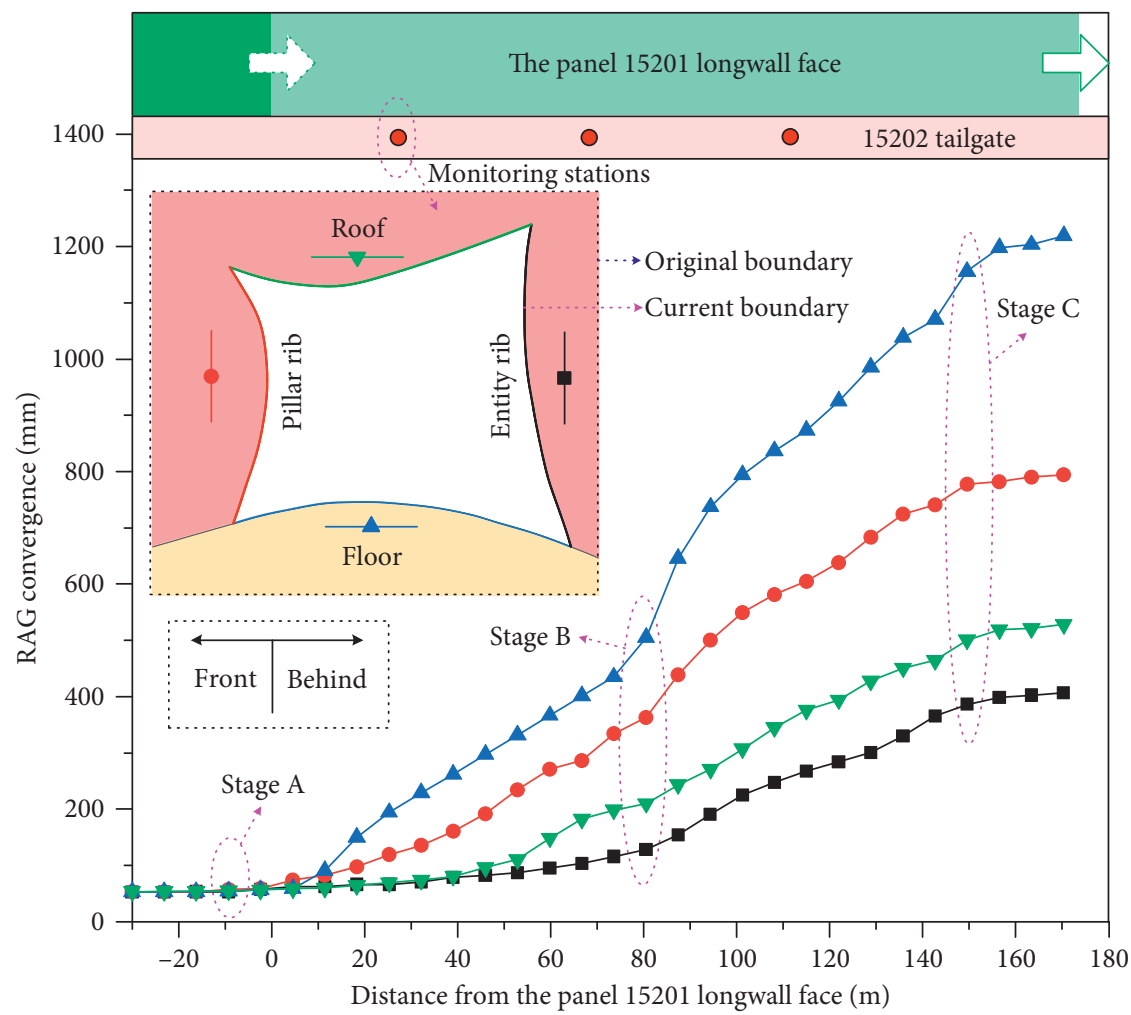

FIGURE 3: Convergence of the 15202 tailgate versus the panel 15201 longwall face retreat (negative and positive numbers indicate the 15201 longwall face was inby and outby the site, respectively).

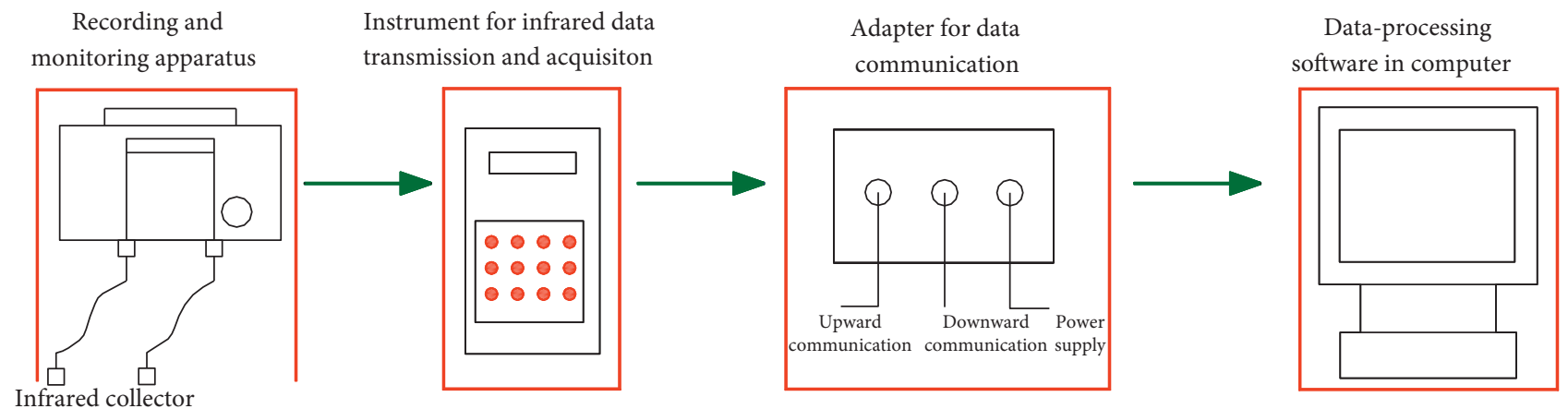

Figure 4: Schematic diagram of continuous borehole stress recorder system.

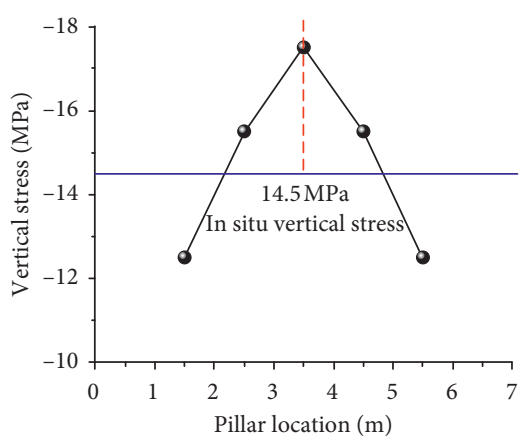

(a)

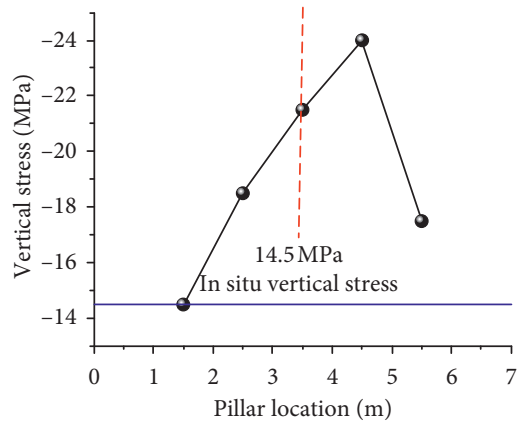

(b)

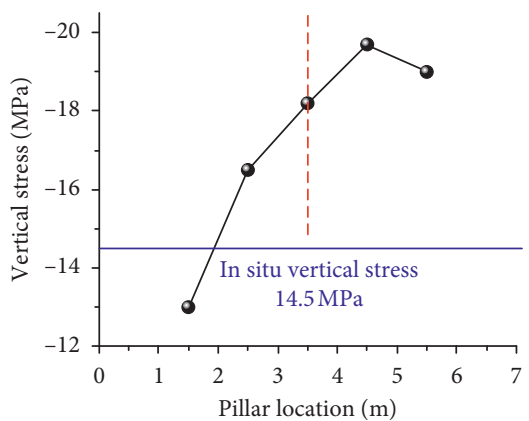

(c)

Figure 5: Abutment load profiles with different distance to the panel 15201 longwall face (negative and positive numbers indicate the 15201 longwall face was inby and outby the site, respectively). (a) Stage A, $-10 \mathrm{~m}$. (b) Stage B, $+80 \mathrm{~m}$. (c) Stage C, $+150 \mathrm{~m}$. 
the formation of O-shaped cracks. The roof can be described as having simple support on all sides. Beyond this, the intermediate position III of the four side simple plates breaks, and finally the inclined crack IV appears as the rock plate recedes from two perpendicular directions toward the intermediate position. Finally, an X-shaped crack forms in the previously formed O-shaped crack [25].

With the advancement of the longwall face, the main roof fails in an O-X pattern, and a curved triangular block structure forms along the edge of the goaf, leading to side abutment pressure applied on the pillar (Figure 6(a)). A certain distance in front of the longwall face (Figure 6(b)), the lateral competent roof, does not break, and limited deformation and damage occur in the tailgate. After the longwall face has passed by (Figures 6(c) and 6(d)), the roof in the vicinity collapses; the coal pillar cannot bear the weight of both the competent roof and the overburden, and so the competent roof rotates at the fracture position and sinks. Due to the large cantilever length of the competent roof, the rotation angle $\theta$ gradually increases during the sinking process, causing substantial deformation of the tailgate.

In order to examine the horizontal stresses caused by the rotation of the competent roof and the resulting severe floor heave in the tailgate, a numerical study was performed based on the geological and mining condition of the 15202 tailgate.

\section{Numerical Modeling}

3.1. Model Configuration. A 3D numerical model was built using the finite difference software package FLAC ${ }^{3 \mathrm{D}}$ [26]. The model size was $420 \mathrm{~m} \times 400 \mathrm{~m} \times 75 \mathrm{~m}$. $0.5 \mathrm{~m}$ fine mesh was used in the interest area containing the 15201 longwall pane, the 15201 headgate, and the 15202 tailgate (Figure 7). Larger meshes were used in other areas for computational efficiency. All the lateral boundaries were fixed in the normal direction. The bottom boundary was fixed in the vertical direction. A vertical stress of $13.58 \mathrm{MPa}$ was applied to the top boundary to simulate the overburden stress. The strain-softening model was used to describe the behavior of the coal seam. All other rock masses were represented using the Mohr-Coulomb model. The behavior of the goaf was simulated using the double-yield model. In general, the numerical model was solved in four steps (Figure 8) following the operations of underground mining activities. The global model was generated and the geostatic stress condition was applied in the first step. In the second step, the 15201 headgate and 15202 tailgate were developed. Then the 15201 panel was excavated by step in the third step. In the fourth step, the numerical simulation data of three different distances between tailgate and 15201 longwall face are collected, respectively.

\subsection{Strain-Softening Model and Parameters of the Coal Pillar.} A precise simulation of the mechanical behavior of rock mass plays a key role in numerical modeling. A yielding coal pillar is generally modeled as a nonlinear strain-softening material using a function of plastic strain to soften the cohesion and friction [27-31]. The parameters of the strain-softening model can be determined by trial and error until the simulated behavior of the coal pillar is consistent with that calculated by an empirical formula. The calibrated parameters are listed in Table 1. It is worth noting that the strain-softening model in FLAC $^{3 \mathrm{D}}$ requires that the initial parameters and postpeak parameters be predetermined (see in Table 1). The initial parameters are used to define the peak strength of the material, and the postpeak parameters control the mechanical properties of the material after yielding.

\subsection{Double-Yield Model and Parameters of the Goaf}

3.3.1. Simulating the Goaf Using the Double-Yield Model. The goaf can be represented as a strain hardening material. After its initial height becomes compacted, the material will become harder and the modulus will increase. The doubleyield model can be used to simulate the behavior of a strain hardening material in FLAC ${ }^{3 \mathrm{D}}$. The purpose of this model is to indicate that, in addition to shear yielding, there may be significant irreversible compaction of the material. Therefore, the double-yield model is widely used in many studies to simulate goaf materials [32-36]. However, since relevant goaf data is unavailable and difficult to obtain on site, it is challenging to model the behavior of the goaf's composite [37]. The input data required to build the double-yield model of the goaf includes stress-strain data, shear modulus, bulk modulus, and material friction angle. The stress-strain relationship is derived from the Salamon model as shown in equation (1) [38]. Other parameters are obtained by an iterative technique using a uniaxial compression test model, as described below.

$$
\sigma=\frac{E_{0} \varepsilon}{1-\left(\varepsilon / \varepsilon_{\mathrm{m}}\right)}
$$

where $\sigma$ is the axial stress applied on the material under unconfined conditions, $\varepsilon$ is the axial strain, $E_{0}$ is the initial shear modulus, and $\varepsilon_{\mathrm{m}}$ is the maximum strain; $\varepsilon_{\mathrm{m}}$ can be calculated as

$$
\begin{aligned}
& E_{0}=\frac{10.39 \sigma_{\mathrm{c}}^{1.042}}{b^{7.7}}, \\
& \varepsilon_{\mathrm{m}}=\frac{b-1}{b},
\end{aligned}
$$

where $\sigma_{\mathrm{c}}$ is the compressive strength of the crushed rock and $b$ is the coefficient of expansion of the crushed rock, which is determined by [39]

$$
b=\frac{h_{\mathrm{c}}+h_{\mathrm{cr}}}{h_{\mathrm{cr}}},
$$

where $h_{\mathrm{c}}$ is the mining height and $h_{\mathrm{cr}}$ is the height of the caved zone.

It has been demonstrated that the height of the caved zone is closely related to geological conditions and is about 2 to 8 times the mining height [40]. The mining height of the 15201 longwall panel at Jingfu mine was $5 \mathrm{~m}$. According to gas drilling measurements taken during the mining process, the height of the caved zone was $19.2 \mathrm{~m}$ above the coal seam. According to the equation above, the coefficient of 

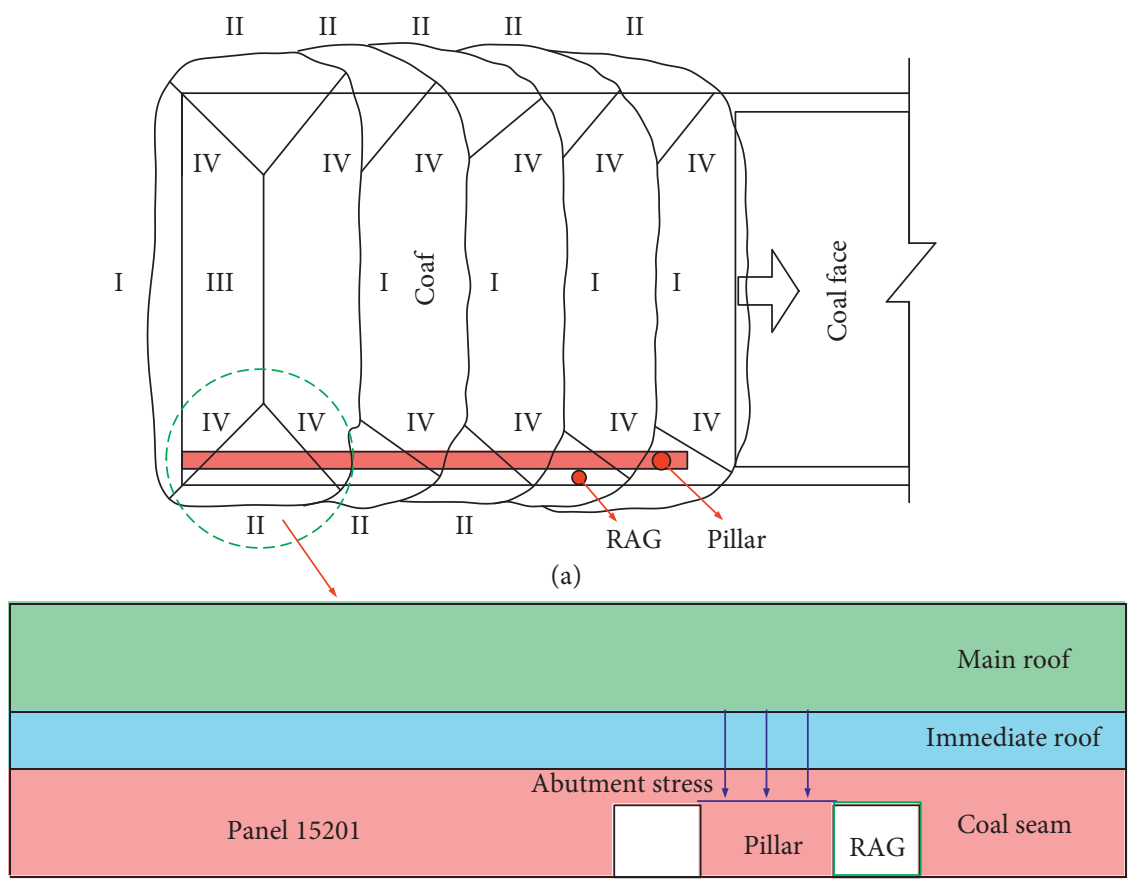

(b)

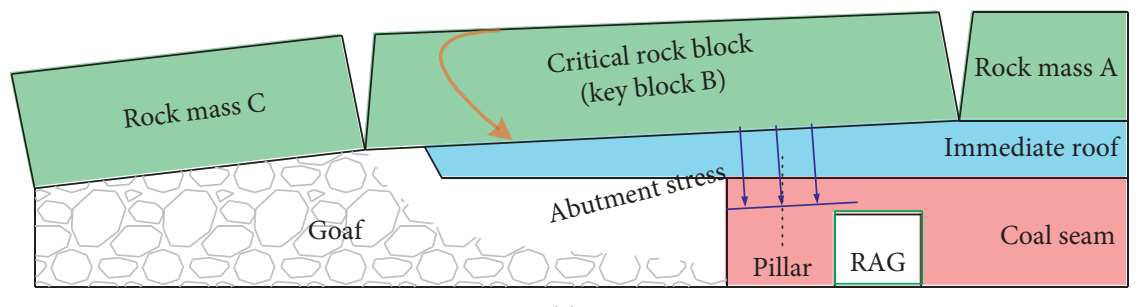

(c)

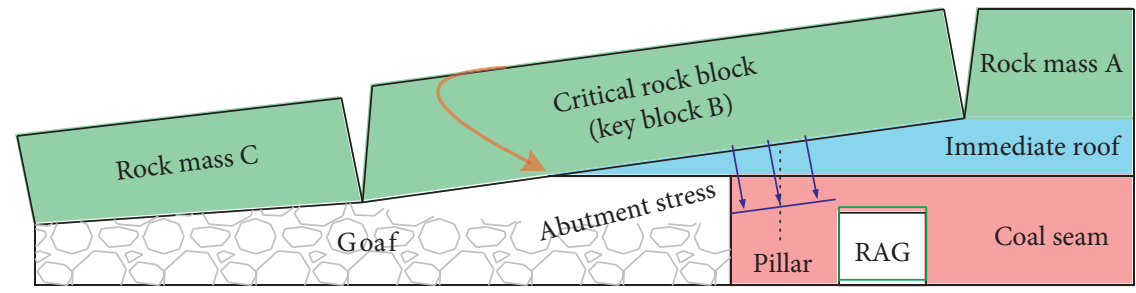

(d)

Figure 6: Failure characteristics of immediate roof above roadway adjacent to goaf (RAG) (negative and positive numbers indicate the 15201 longwall face was inby and outby the site, respectively). (a) O-X failure. (b) Stage A, $-10 \mathrm{~m}$. (c) Stage B, $+80 \mathrm{~m}$. (d) Stage C $+150 \mathrm{~m}$.

expansion, maximum strain, and initial shear modulus of the material in the goaf were estimated to be $1.26,0.21$, and 21.42 $\mathrm{MPa}$, respectively. The "cap pressures" distribution parameters of the double-yield model are listed in Table 2.

The material parameters for the double-yield model can be determined using trial and error until the simulated stress-strain curve is consistent with equation (1). For this purpose, a FLAC ${ }^{3 \mathrm{D}}$ model with a size of $1.0 \mathrm{~m} \times$ $1.0 \mathrm{~m} \times 1.0 \mathrm{~m}$ was created. A constant velocity of $10^{-5} \mathrm{~m} / \mathrm{s}$ was applied to the top boundary of the model, and the displacement of the four lateral boundaries was fixed in their normal directions. The bottom boundary was fixed in the vertical direction. The input parameters were calibrated by iterative changes in the bulk modulus, shear modulus, expansion angle, and friction angle of the goaf material. The stress-strain curve obtained from the numerical model is shown in Figure 9, which is in good agreement with the stress-strain curve obtained using Salamon's model. Table 3 lists the parameters used for simulating the goaf.

3.3.2. Verifying the Parameters for Simulating the Goaf. In order to verify the reliability of the selection of the doubleyield model and its parameters, the vertical stress of each region in the caved zone during mining of the 15201 panel was monitored and plotted in Figure 10. The vertical stress increased from $0.02 \mathrm{MPa}$ at the edge of the goaf to $13.7 \mathrm{MPa}$ at about $105 \mathrm{~m}$ into the goaf and then remains relatively constant. In other words, $94 \%$ of the initial vertical stress (13.7 $\mathrm{MPa} / 14.5 \mathrm{MPa})$ can be recovered at a depth that is $18 \%$ 


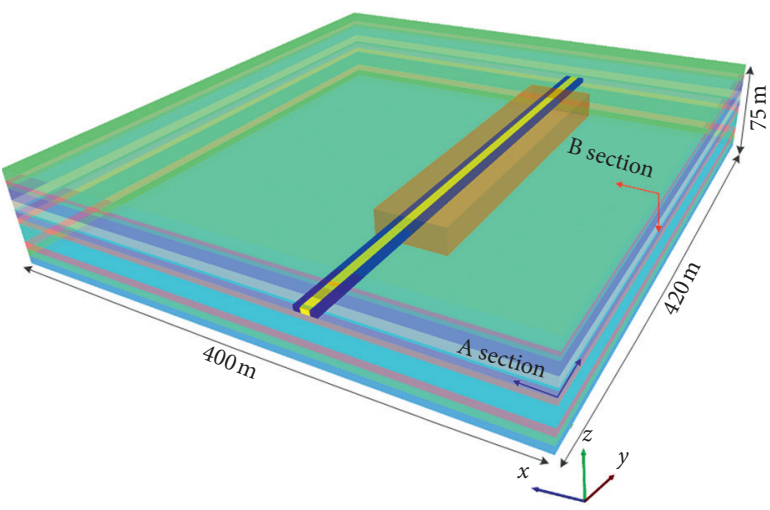

(a)

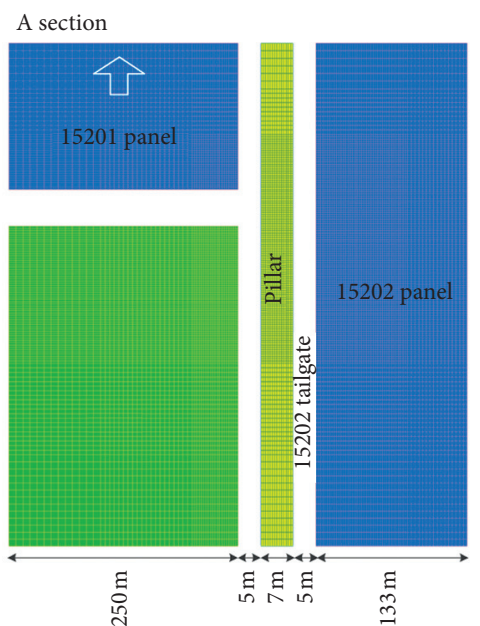

B section

Medium sandstone<smiles>C1CCCCC1</smiles>

$\longrightarrow$ Limestone $(3.0 \mathrm{~m})$

$\longrightarrow$ Fine sandstone $(9.0 \mathrm{~m})$

$\longrightarrow$ Sandy mudstone (7.0

+15 coalseam $(5.0 \mathrm{~m})$

Mudstone $(4.5 \mathrm{~m})$

$\longrightarrow$ Sandy mudstone $(14.5 \mathrm{~m})$

Medium sandston

$(6.0 \mathrm{~m})$

$\rightarrow$ Sandy sandstone $(6.0 \mathrm{~m})$

$\longrightarrow$ Mudstone $(6.0 \mathrm{~m})$

Figure 7: Schematic diagram of the FLAC ${ }^{3 \mathrm{D}}$ numerical model.

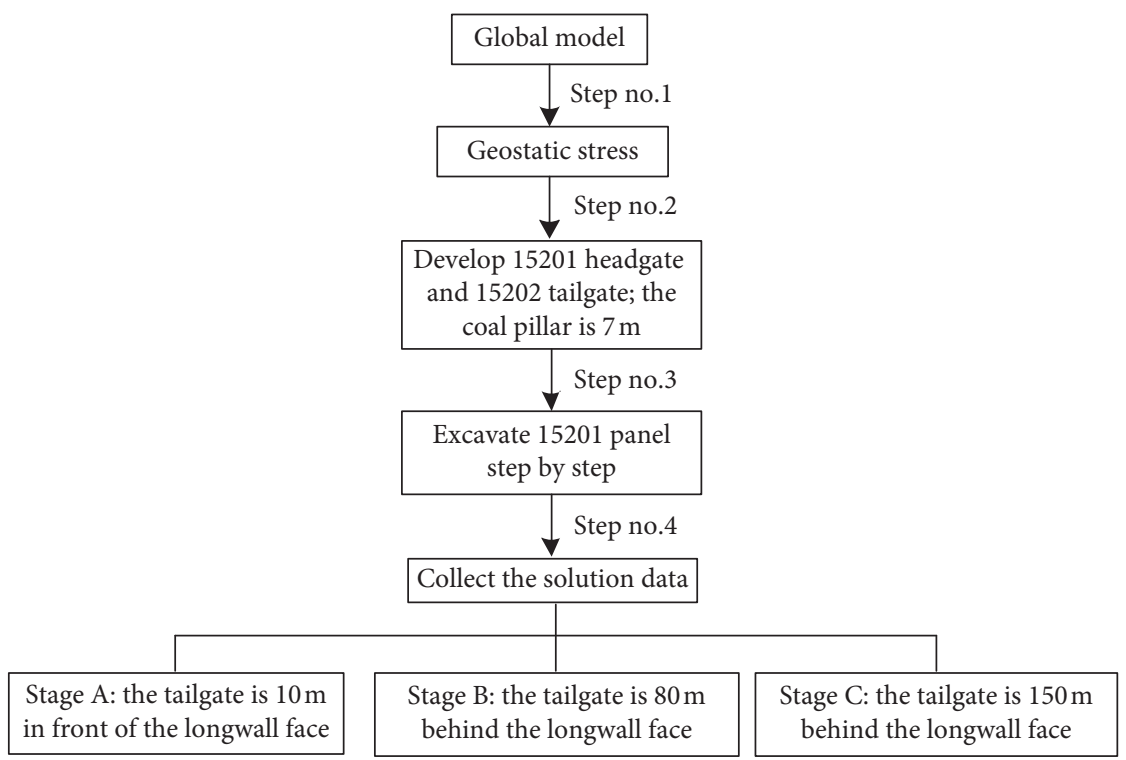

FIgURE 8: Numerical simulation plan.

of the 15201 longwall panel $(105 \mathrm{~m} / 580 \mathrm{~m})$. Based on field measurements, a reasonable estimate of the overburden stress distance should be 0.12 times the depth of the overburden [41, 42]. The investigation and analysis of a large number of roadway stability cases show that the vertical stress increases from zero to the initial stress at a distance of 0.2 to 0.3 times the depth of the overburden [43]. It can be seen that the simulated stress distribution around the 15201 goaf is consistent with the conclusions of other researchers, suggesting that the double-yield model and the parameters (see in Table 3) used adequately capture the behavior of the goaf during the caving and compaction process.

3.4. Verification of the Numerical Model. In order to verify the reliability of the global model, the deformation characteristics of the surrounding rock obtained by the numerical model were compared with field data; see Figure 11. As the 15201 longwall face approached the monitoring point, the deformation of the 15202 tailgate gradually increased. Both the numerical and field data show that when the 15201 longwall face passed by the monitor, the deformation speed of the tailgate increased significantly. The deformation curve obtained by the numerical simulation aligned well with the measured data. The corresponding parameters of rock strata are listed in Table 4.

\section{Study on the Mechanism of Floor Heave Caused by the Fracturing of a Competent Roof}

4.1. Horizontal Displacement of the Pillar. The simulated horizontal displacement of the 15202 tailgate is shown in 
TABLE 1: Strain-softening parameters for chain pillar material.

\begin{tabular}{lcccc}
\hline Initial parameters & Strain $(\mathrm{mm} / \mathrm{mm})$ & \multicolumn{2}{c}{ Postpeak parameters } \\
Parameter & Value & 0 & Cohesion $(\mathrm{MPa})$ & 1.3 \\
\hline Density $\left(\mathrm{kg} / \mathrm{m}^{3}\right)$ & 1400 & 0.025 & 0.9 & 25 \\
Bulk modulus $(\mathrm{GPa})$ & 1.5 & 0.050 & 0.7 & 22 \\
Shear modulus $(\mathrm{GPa})$ & 1.2 & 0.075 & 0.5 & 20 \\
Cohesion $(\mathrm{MPa})$ & 1.3 & 0.010 & 0.4 & 18 \\
Friction angle $\left({ }^{\circ}\right)$ & 25 & 1.0 & 0.4 & 16 \\
Tension strength $(\mathrm{MPa})$ & 0.43 & & & \\
\hline
\end{tabular}

TABle 2: Cap pressures for the double-yield model.

\begin{tabular}{lccc}
\hline Strain $(\mathrm{m} / \mathrm{m})$ & Stress $(\mathrm{MPa})$ & Strain $(\mathrm{m} / \mathrm{m})$ & Stress $(\mathrm{MPa})$ \\
\hline 0.01 & 0.22 & 0.11 & 4.95 \\
0.02 & 0.47 & 0.12 & 6.00 \\
0.03 & 0.75 & 0.13 & 7.31 \\
0.04 & 1.06 & 0.14 & 9.00 \\
0.05 & 1.41 & 0.15 & 11.25 \\
0.06 & 1.80 & 0.16 & 14.39 \\
0.07 & 2.25 & 0.17 & 19.12 \\
0.08 & 2.77 & 0.18 & 27.00 \\
0.09 & 3.37 & 0.19 & 42.73 \\
0.10 & 4.09 & 0.20 & 90.00 \\
\hline
\end{tabular}

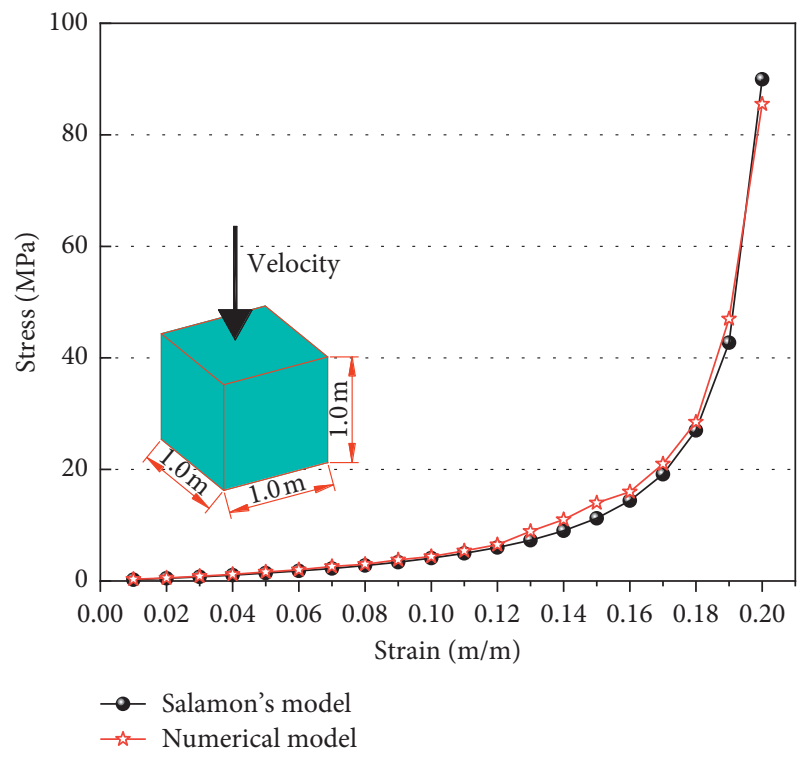

Figure 9: Comparison of the stress-strain curve between the numerical model and Salamon's model.

Figure 12. Coal pillars of different height ranges display varying displacement distribution characteristics.

When the 15201 longwall face was $10 \mathrm{~m}$ inby, the horizontal displacement of the coal pillars at different heights was symmetrical across the width of the pillar. The horizontal displacement at different depths in the pillar varied between $-3.0,-2.8,-1.9,-1.0$, and $0 \mathrm{~cm}$ on the goaf side and between $2.7,2.5,2.3,1.6$, and $0.04 \mathrm{~cm}$ on the tailgate side. The zone of zero horizontal displacement was located at the core of the coal pillar $(x=3.5 \mathrm{~m})$ at different heights.
At $80 \mathrm{~m}$ behind the working face of 15201, the horizontal displacement at different heights of the coal pillar was no longer symmetrical across the width of the pillar. The horizontal displacement at different depths in the pillar was $-42.4,-34.2,-26.0,-24.3$, and $0 \mathrm{~cm}$ on the goaf side and $55.0,46.9,41.4,37.3$, and $26.5 \mathrm{~cm}$ on the tailgate side. The horizontal displacement of the coal pillar on the tailgate side was greater than that of the goaf side, and the zero-displacement zone was offset toward the goaf $(x<3.5 \mathrm{~m})$.

At $150 \mathrm{~m}$ behind the working face of 15201 , the horizontal displacement of the coal pillar at different heights was no longer symmetrical across the width of the pillar. The horizontal displacement at different depths in the pillar was $-61.1,-49.3,-40.1,-30.8$, and $-20.3 \mathrm{~cm}$ on the goaf side and $79.8,72.8,64.8,52.1$, and $37.7 \mathrm{~cm}$ on the tailgate side. The horizontal displacement on the tailgate side of the coal pillar was significantly greater than that on the goaf side, and the zero-displacement zone shifted further toward the goaf $(x<3.0 \mathrm{~m})$.

As the 15201 longwall face advanced, the competent roof fractured and sank, following the zero-horizontal displacement zone in the direction of the goaf and significantly inducing floor heave in the tailgate.

4.2. Vertical Stress and Floor Heave Characteristics of the Tailgate. Figure 13 shows the simulated vertical stress distribution in the middle of the coal pillar in the three stages. It can be seen that the vertical stress characteristics within the coal pillar differed across the three stages. When the 15201 longwall face was $10 \mathrm{~m}$ inby the monitoring station, the vertical stress on the coal pillar was symmetrical across the width of the coal pillar, and a peak value of 18.1 MPa occurred in the center of the pillar, leading to zero offset between the peak zone and the center of the coal pillar. When the 15201 longwall face was $80 \mathrm{~m}$ outby the monitoring station, the peak vertical stress was $23.6 \mathrm{MPa}$ and was offset $1.0 \mathrm{~m}$ from the center of the coal pillar. When the 15201 longwall face was $150 \mathrm{~m}$ outby the monitoring station, the peak vertical stress was $20 \mathrm{MPa}$ and was offset $1.5 \mathrm{~m}$ from the center of the coal pillar. As the 15201 longwall face advanced, the immediate competent roof fractured and sank, leading the area of peak vertical stress to be offset toward the tailgate. Although the peak vertical stress in the coal pillar reduced to some extent, the offset continued to increase, causing severe floor heave in the tailgate. 
TABLE 3: Material parameters for simulating goaf.

\begin{tabular}{lccccc}
\hline Parameter & Density $\left(\mathrm{kg} / \mathrm{m}^{3}\right)$ & Bulk modulus $(\mathrm{GPa})$ & Shear modulus $(\mathrm{GPa})$ & Dilation $\left(^{\circ}\right)$ & Friction $\left(^{\circ}\right)$ \\
\hline Value & 1500 & 10.78 & 9.15 & 7 & 18 \\
\hline
\end{tabular}

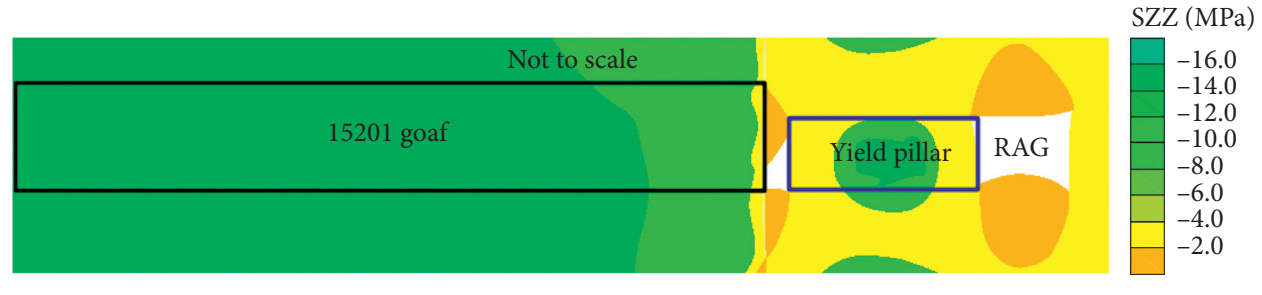

FIGURE 10: Mining-induced vertical stress of the panel 15201 goaf.

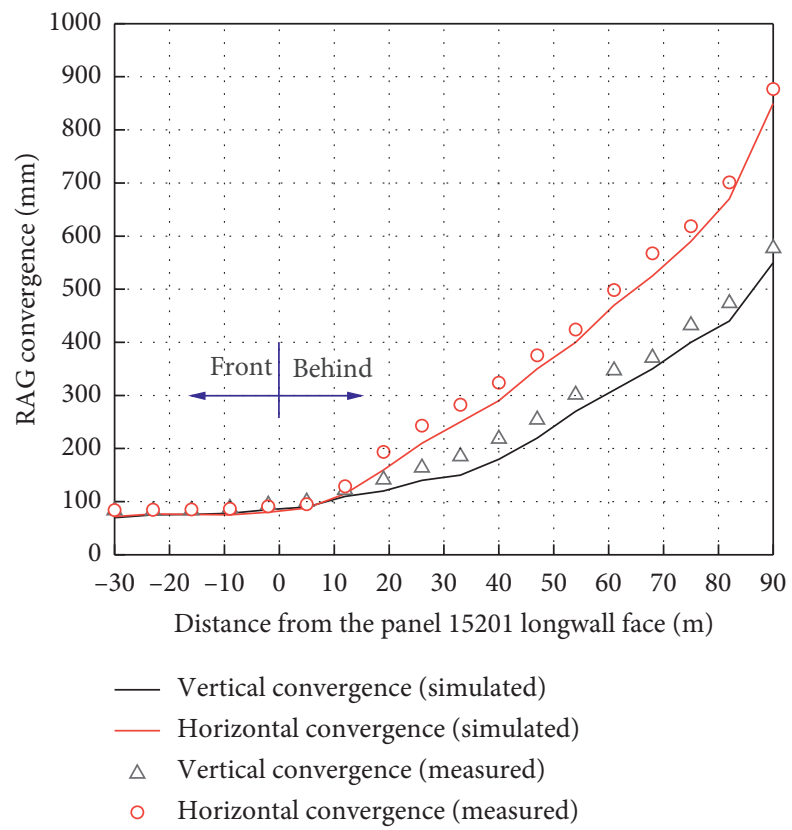

Figure 11: Comparison of 15202 tailgate convergence predicted by numerical simulation and field measurement.

TABLE 4: Rock/coal strata parameters used in the numerical model.

\begin{tabular}{lcccccc}
\hline Rock strata & $\begin{array}{c}\text { Density } \\
\left(\mathrm{kg} / \mathrm{m}^{3}\right)\end{array}$ & $\begin{array}{c}\text { Bulk } \\
\text { modulus }(\mathrm{GPa})\end{array}$ & $\begin{array}{c}\text { Shear } \\
\text { modulus }(\mathrm{GPa})\end{array}$ & Cohesion $(\mathrm{MPa})$ & Friction angle $\left(^{\circ}\right)$ & Tension strength $(\mathrm{MPa})$ \\
\hline Mudstone & 2150 & 3.3 & 0.9 & 5.4 & 25 & 0.32 \\
Fine sandstone & 2510 & 5.0 & 3.0 & 2.0 & 32 & 1.35 \\
Sandy mudstone & 2400 & 4.0 & 2.2 & 2.6 & 30 & 1.12 \\
Limestone & 2700 & 10 & 6.6 & 5.5 & 25 & 1.50 \\
Coal seam & 1400 & 1.5 & 1.2 & 1.3 & 30 & 0.43 \\
Medium sandstone & 2500 & 3.2 & 2.6 & 2.0 & & 1.23 \\
\hline
\end{tabular}

It can be seen from Figure 13 that the floor heave characteristics differed across the three stages. When the 15201 longwall face was $10 \mathrm{~m}$ inby the monitoring station, the maximum floor heave was $5.0 \mathrm{~cm}$ and occurred at the center of the roadway. When the 15201 longwall face was $80 \mathrm{~m}$ outby the monitoring station, the maximum floor heave rapidly increased to $57.6 \mathrm{~cm}$; the position of the maximum floor heave was at $x=2 \mathrm{~m}$ and was offset $0.5 \mathrm{~m}$ from the coal pillar. When the 15201 longwall face was $150 \mathrm{~m}$ outby the monitoring station, the maximum floor heave rapidly increased to $101 \mathrm{~cm}$; the position of the maximum floor heave was at $x=2 \mathrm{~m}$ and was offset $0.5 \mathrm{~m}$ from the coal pillar. The area of severe floor heave was biased toward the coal pillar side. 

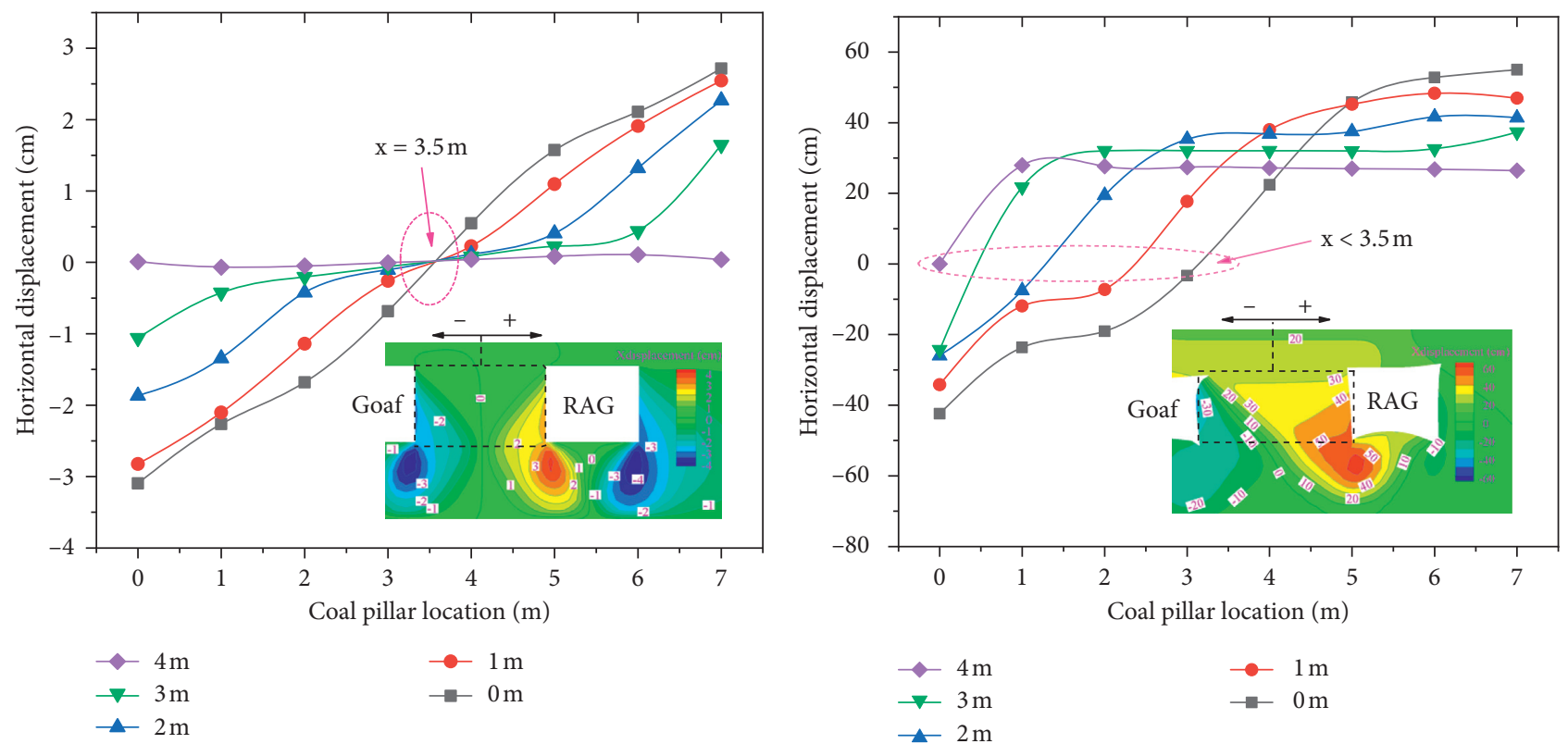

(a)

(b)

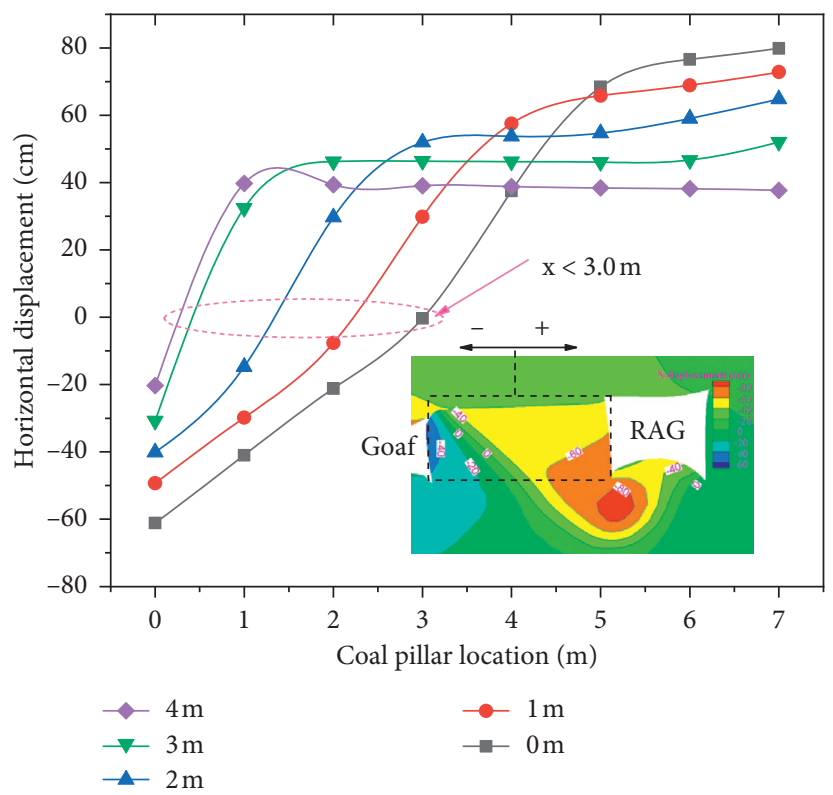

(c)

Figure 12: Simulated distributions of horizontal displacement within the pillar in the three stages. (a) Stage A. (b) Stage B. (c) Stage C.

4.3. Orientation of Principal Stress within the Coal Pillar. Figure 14 shows the distribution of the orientation of maximum principal stress within the coal pillar between the 15202 tailgate and the 15201 headgate. Dramatic changes in the orientation of the maximum principal stress were observed in the three stages.

When the 15201 longwall face was $10 \mathrm{~m}$ inby the monitoring station, the angle between the orientation of the maximum principal stress and the vertical direction of the coal pillar was $0^{\circ}$. When the 15201 longwall face was $80 \mathrm{~m}$ outby the monitoring station, the same angle increased to $20^{\circ}$. When the 15201 longwall face was $150 \mathrm{~m}$ outby the monitoring station, the angle increased to $45^{\circ}$. As the 15201 longwall face advanced, the key block B (in Figure 6) above the coal pillar in the adjacent tailgate resulted in rotation, and the maximum principal stress gradually rotated from a vertical orientation to a horizontal orientation until the main roof reached a steady state beyond which the maximum principal stress orientation angle no longer changed. In this process, the vertical subsidence of the roof gradually formed a lateral horizontal pressure which was applied to the surrounding rock of the coal pillar and the tailgate, thereby contributing significantly to floor heave in the tailgate. 


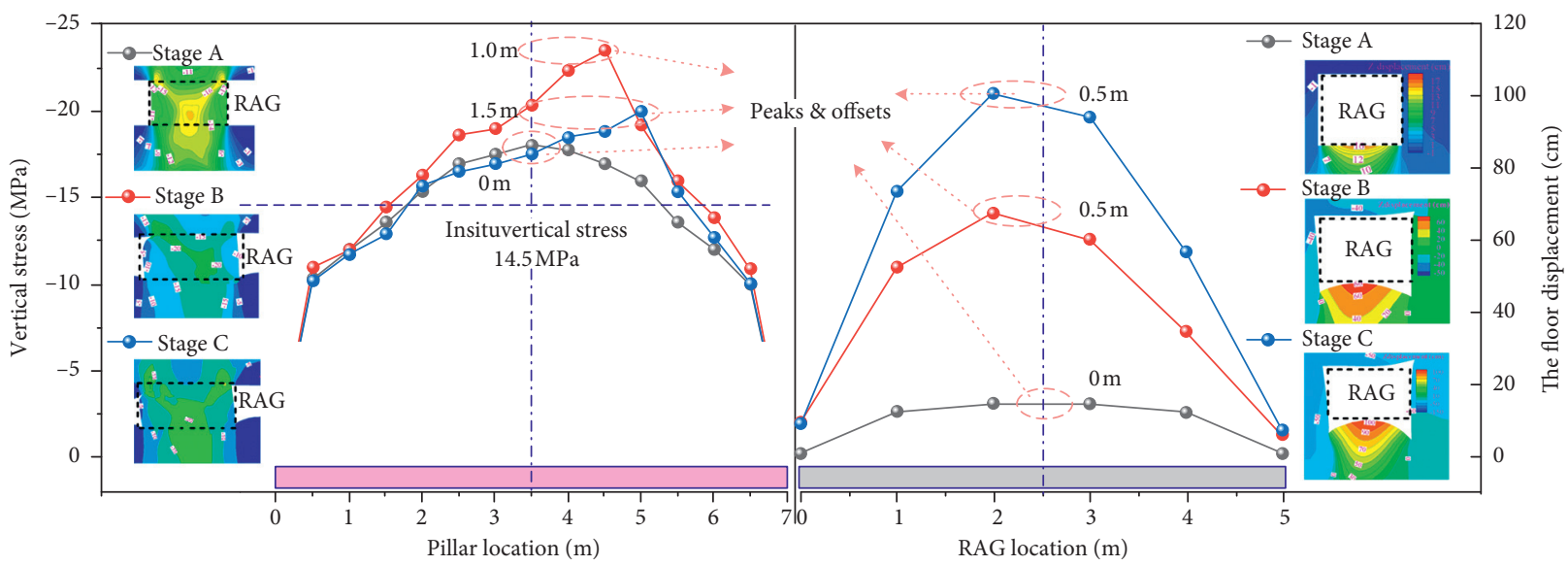

FIGURE 13: Simulated stress distribution and floor heave in the three stages.

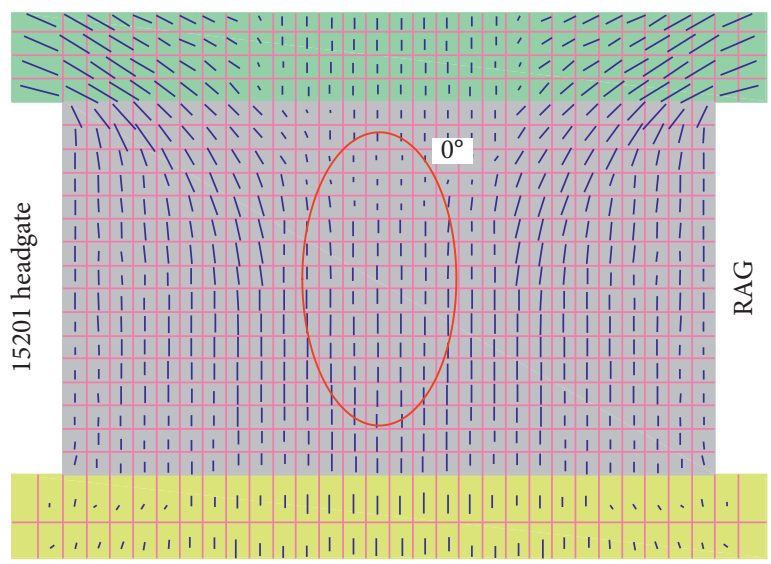

(a)

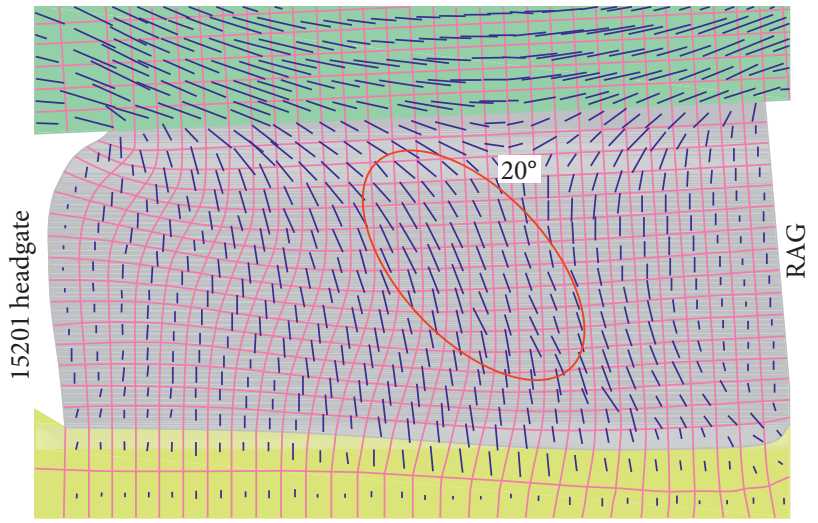

(b)

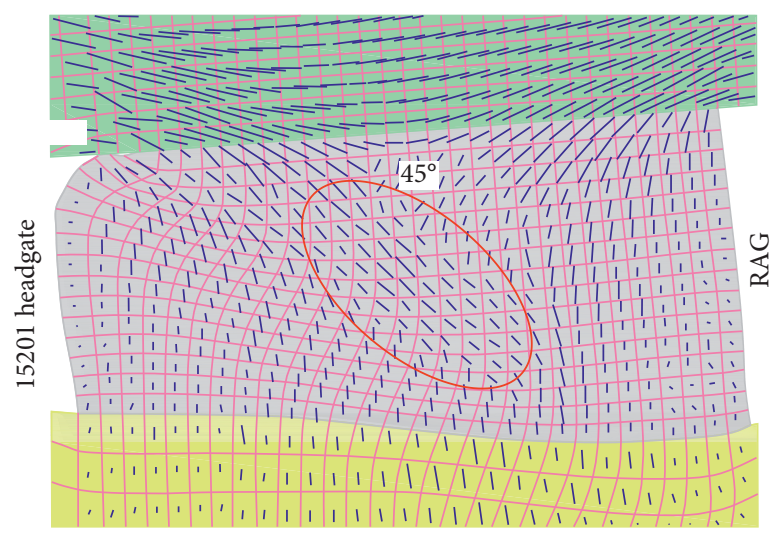

(c)

FIGURE 14: Change of the orientation of the maximum principal stress in the three stages (negative and positive numbers indicate the 15201 longwall face was inby and outby the site, respectively). (a) Stage A, $-10 \mathrm{~m}$. (b) Stage B, $+80 \mathrm{~m}$. (c) Stage C, $+150 \mathrm{~m}$.

4.4. Mechanism of Floor Heave in the Tailgate. From the above research, we obtained two primary causal factors for the floor heave which followed the breaking of the competent roof.

First, the horizontal displacement and variation in the maximum principal stress orientation within the coal pillar demonstrate that, in the process of fracturing in the competent roof, the orientation of the maximum principal stress within the $7 \mathrm{~m}$ wide coal pillar gradually inclined from the vertical direction to the horizontal direction until it had rotated $45^{\circ}$. The horizontal stress generated in the $7 \mathrm{~m}$ wide coal pillar also gradually increased, causing severe floor heave in the tailgate. In addition, as the competent roof began to fracture, the horizontal displacement across the 


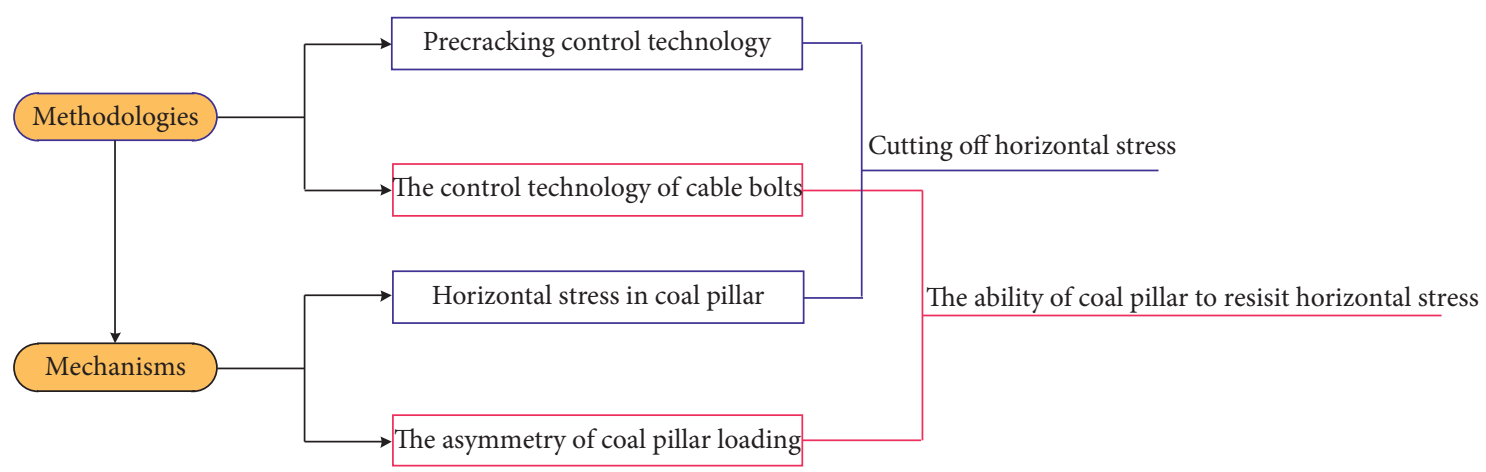

FIgURE 15: Proposed methods for controlling floor heave in the RAG.

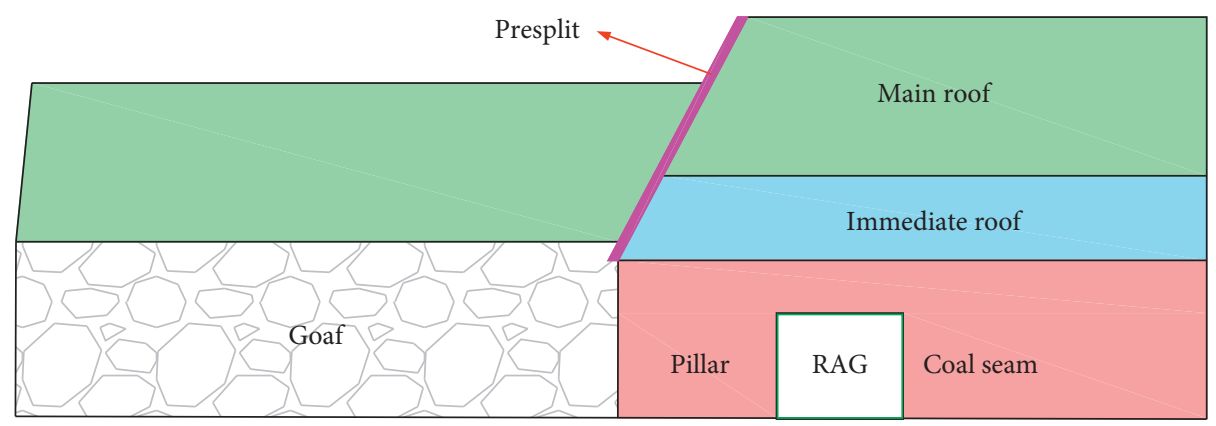

FIGURE 16: Roof structures over the RAG after presplitting blasting in roof.

width of the coal pillar became asymmetrically distributed. The zero-horizontal-displacement zone moved from the center of the coal pillar toward the goaf. Although the stress environment in the $7 \mathrm{~m}$ wide coal pillar did not increase with the support pattern that was in place, the zone of peak vertical stress gradually moved from the center of the pillar to the tailgate side. The offset of the zero-horizontal-displacement zone and the peak-vertical-stress zone caused instability in the coal pillar and subsequent floor heave in the tailgate.

\section{Technology for Controlling Floor Heave of the Tailgate}

5.1. Support Principles. Based on the two causal factors of floor heave discussed above, the following technologies are proposed for controlling the floor heave in the tailgate (Figure 15).

\subsubsection{Directional Energy Presplitting Blasting Technology.} As the competent roof above the coal pillar fracturing (see in Figures 6(b) and 6(d)), the key block B gradually rotated, thereby also rotating the orientation of the maximum principal stress from a vertical direction to a horizontal direction. The rotation increased the horizontal stress applied to the pillar. This is the primary reason for severe floor heave in the tailgate. Therefore, we propose treating the competent roof before the formation of the roof structure to reduce the roof's lateral fracture length and cut off the roof above the pillar. This could be done by controlling the position of the fracture using directional energy presplitting blasting technology, for example, and would result in reducing the impact of the horizontal stress on the coal pillar, as shown in Figure 16.

5.1.2. Technique for Limiting the Horizontal Displacement of Coal Pillars by Pulling Anchor Cables. The mechanical properties of coal pillars, such as the elastic modulus and compressive strength, can be improved by installing cable bolts across the entire width of the coal pillar. The cable bolts would increase a pillar's interlayer pressure by holding the rock layers together and thus increasing their ability to resist deformation and damage from horizontal stress.

5.2. Field Practice. Directional energy presplitting blasting was performed in the main roof of the coal pillar $100 \mathrm{~m}$ ahead of the 15201 longwall face. As shown in Figure 17, $10 \mathrm{~m}$ long boreholes were drilled into the tailgate roof at an incline of $40^{\circ}$ from the roof line. The collar of the boreholes was $100 \mathrm{~mm}$ away from the pillar. The boreholes were spaced at $400 \mathrm{~mm}$ increments along the direction of the tailgate. Presplitting blasting was not performed in all the boreholes but rather in a "blasting-guiding-blasting" pattern; see Figure 18. Cable bolts were installed across the entire width of the pillar with a spacing pattern of $1.6 \mathrm{~m}$ by $1.6 \mathrm{~m}$. The cable bolts were $7.3 \mathrm{~m}$ long and $21.8 \mathrm{~mm}$ in diameter and were anchored at both ends using steel ladder beam and nuts (see Figure 17). 


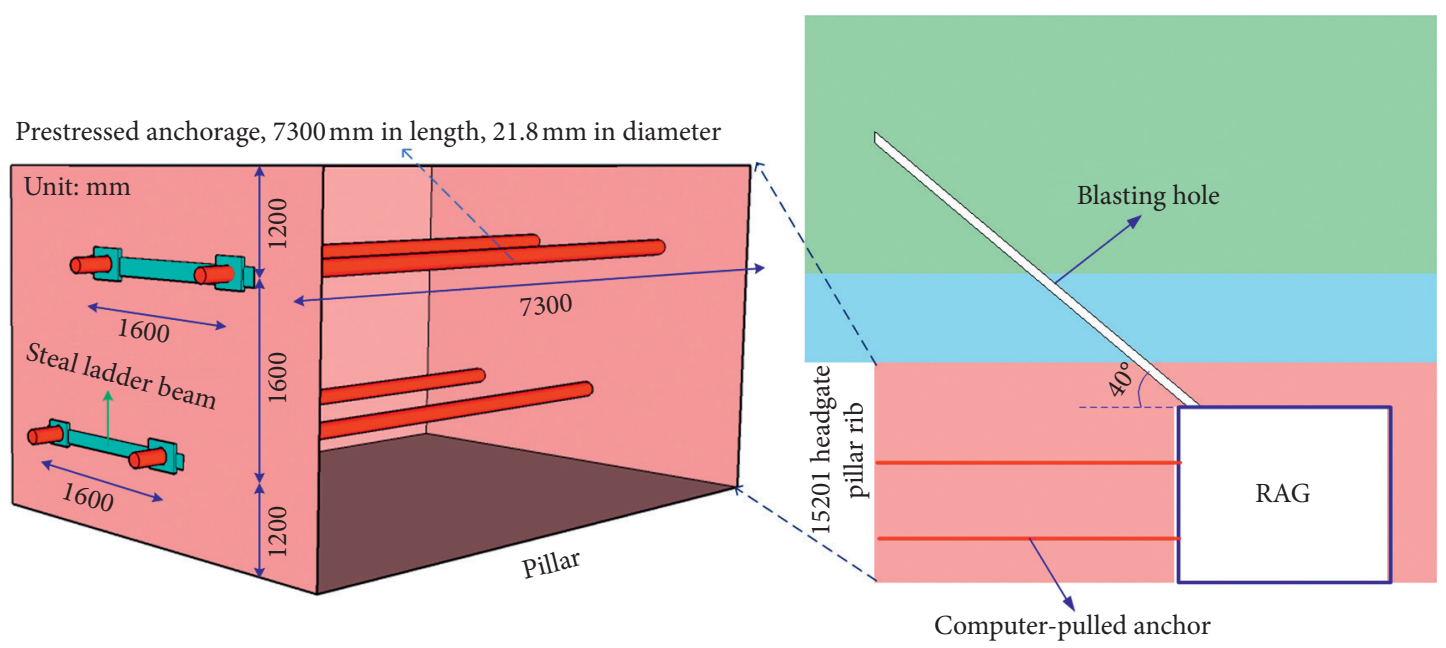

FIGURE 17: Controlling pattern of the 15202 tailgate.

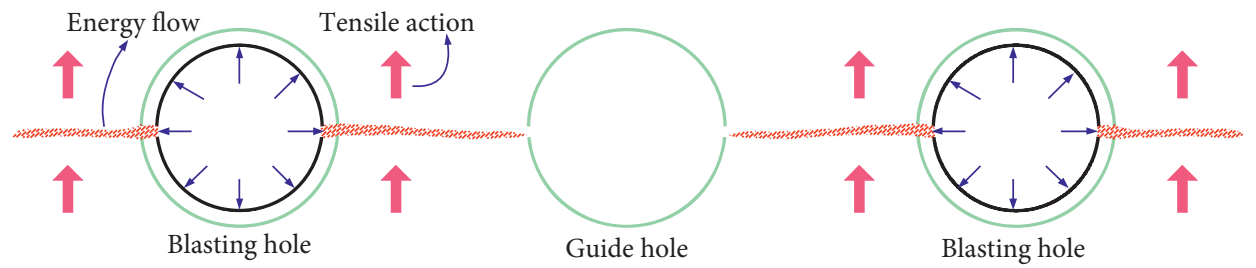

FIGURE 18: Sketch of the "blasting-guiding-blasting" pattern.

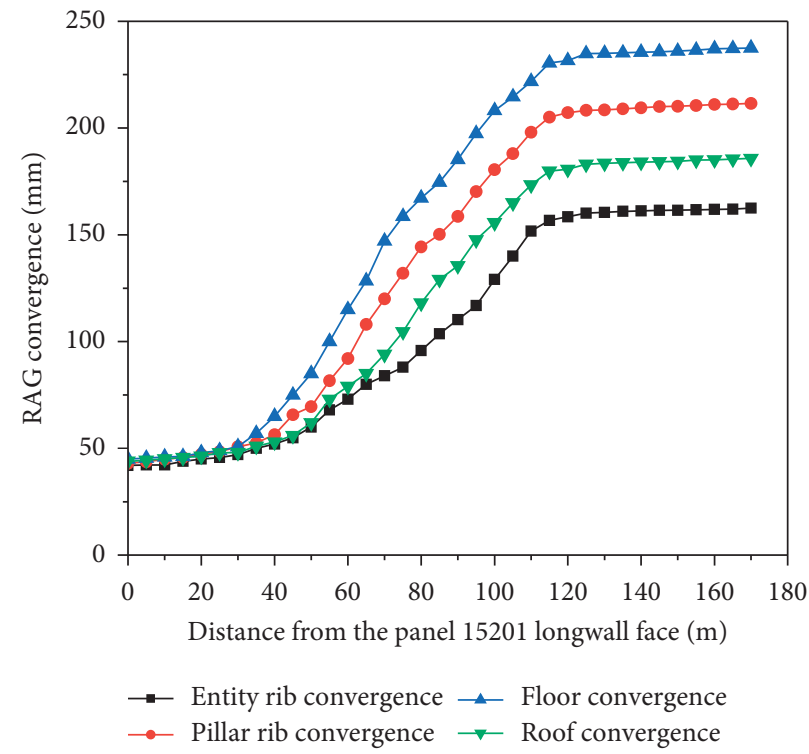

FIGURE 19: Measured convergences in the 15202 tailgate after using the proposed technologies.

5.3. Field Monitoring. Figure 19 shows the deformation of the 15202 tailgate after directional energy presplitting blasting was conducted and cable bolts were installed. The 15202 tailgate stabilized when the 15201 longwall face was $120 \mathrm{~m}$ outby. The inward deformation of the coal pillar rib and the deformations of the solid coal rib, the floor heave, and the roof sag were $210 \mathrm{~mm}, 160 \mathrm{~mm}$,
$230 \mathrm{~mm}$, and $180 \mathrm{~mm}$, respectively. In contrast to the section of the 15202 tailgate that received no preblasting and cable bolting, the deformation of the coal pillar rib and the floor was reduced by $72.7 \%$ and $80.2 \%$, respectively, suggesting that the proposed technologies successfully controlled the floor heave caused by high horizontal stress. 


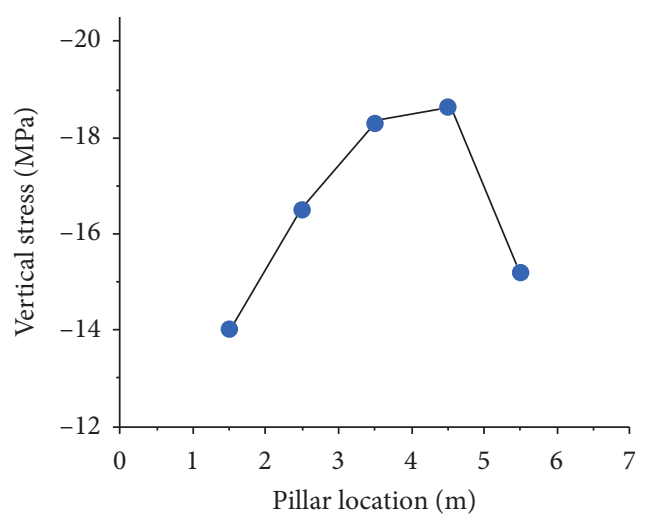

(a)

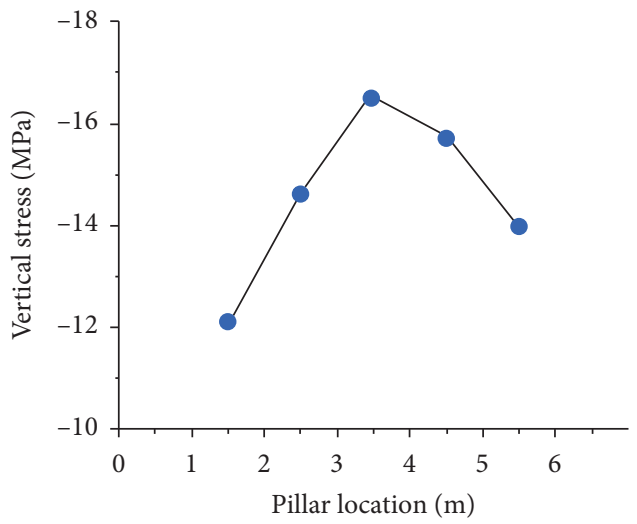

(b)

Figure 20: The stress distribution in the coal pillar after using the proposed technologies. (a) Location: $+80 \mathrm{~m}$. (b) Location: $+150 \mathrm{~m}$.

Figure 20 shows the stress distribution in the coal pillar after directional energy presplitting blasting was conducted and cable bolts were installed. In contrast to the section of the coal pillar that received no preblasting and cable bolting, the maximum vertical stress within the coal pillar and the offsets of the position of the maximum vertical stress reduces obviously, which verifies the rationality of the choice of the proposed control technologies.

\section{Conclusions}

In this paper, a field study and numerical modeling were carried out to examine the influence of pillar deformation, pillar stress, and maximum principal stress orientation on the floor heave of a tailgate driven along a goaf. The following conclusions can be drawn.

The mechanisms of severe floor heave in a tailgate driven along a goaf can be described as follows: the key block B gradually spins down from the cantilever state, causing a gradual increase in the horizontal stress applied to the pillar. Further, the zero-horizontal-displacement zone and the peak-vertical-stress zone are offset from the center of the coal pillar, resulting in the overall instability of the coal pillar.

Two control technologies are proposed: First, the lateral competent roof is manually cut using directional energy presplitting blasting cuts to eliminate the influence of horizontal stress on the coal pillar. Second, cable bolts are installed across the width of the pillar to constrain horizontal displacement and increase the pillar's ability to sustain horizontal stress.

When using the proposed control strategies, the maximum floor heave was only $230 \mathrm{~mm}$ when the longwall face was $120 \mathrm{~m}$ outby. This proposed technology could help control floor heave in tailgates within two-entry longwall systems with narrow coal pillars.

\section{Data Availability}

All data included in this study are available upon request by contacting the corresponding author.

\section{Conflicts of Interest}

The authors declare no conflicts of interest.

\section{Authors' Contributions}

Shuaigang Liu and Jianbiao Bai contributed to conceptualization; Xiangyu Wang contributed to methodology; Shuaigang Liu and Xiangyu Wang contributed to formal analysis and investigation; Shuaigang Liu provided the software; Bowen $\mathrm{Wu}$ and Wenda Wu contributed to validation; Jianbiao Bai contributed to funding acquisition.

\section{Acknowledgments}

This research was financially supported by the Fundamental Research Funds for the Central Universities (2018ZDPY02).

\section{References}

[1] W.-D. Wu, J.-B. Bai, X.-Y. Wang, S. Yan, and S.-X. Wu, "Numerical study of failure mechanisms and control techniques for a gob-side yield pillar in the Sijiazhuang coal mine, China," Rock Mechanics and Rock Engineering, vol. 52, no. 4, pp. 1231-1245, 2019.

[2] H. W. Zhang, Z. J. Wan, Z. Y. Ma, and Y. Zhang, "Stability control of narrow coal pillars in gob-side entry driving for the LTCC with unstable overlying strata: a case study," Arabian Journal of Geosciences, vol. 11, no. 21, 2018.

[3] J.-B. Bai, W.-L. Shen, G.-L. Guo, X.-Y. Wang, and Y. Yu, "Roof deformation, failure characteristics, and preventive techniques of gob-side entry driving heading adjacent to the advancing working face," Rock Mechanics and Rock Engineering, vol. 48, no. 6, pp. 2447-2458, 2015.

[4] A. M. Rao, S. V. S. S. Ramalingeswarudu, and G. Venkateswarlu, "Planning of ventilation requirements for deep mechanised longwall faces-a case study of Adriyala longwall project of the Singareni collieries company limited (SCCL)," Procedia Earth and Planetary Science, vol. 11, pp. 548-556, 2015.

[5] Q. S. Bai, S. H. Tu, F. T. Wang, and C. Zhang, "Field and numerical investigations of gateroad system failure induced 
by hard roofs in a longwall top coal caving face," International Journal of Coal Geology, vol. 173, pp. 176-199, 2017.

[6] D. R. Zhu, Breakage law of the main roof of longwall face and its application, Ph.D. thesis. China University of Mining and Technology. Xuzhou, China, 1987, in Chinese.

[7] X. Cai, Z. Zhou, and X. Du, "Water-induced variations in dynamic behavior and failure characteristics of sandstone subjected to simulated geo-stress," International Journal of Rock Mechanics and Mining Sciences, vol. 130, Article ID 104339, 2020.

[8] L. Jiang, P. Kong, P. Zhang et al., "Dynamic analysis of the rock burst potential of a longwall panel intersecting with a fault," Rock Mechanics and Rock Engineering, vol. 53, no. 4, pp. 1737-1754, 2020.

[9] L. Jiang, P. Kong, J. Shu, and K. Fan, "Numerical analysis of support designs based on a case study of a longwall entry," Rock Mechanics and Rock Engineering, vol. 52, no. 9, pp. 3373-3384, 2019.

[10] X. H. Li, M. H. Ju, Q. L. Yao, J. Zhao, and Z. Zhao, "Numerical investigation of the effect of the location of critical rock block fracture on crack evolution in a gob-side filling wall," Rock Mechanics and Rock Engineering, vol. 49, no. 3, pp. 1041-1058, 2016.

[11] Y. J. He, "Prediction of breaking position of face end suspended roof in roadway adjacent to a goaf," Journal of China Coal Society, vol. 25, no. 1, pp. 30-33, 2000, in Chinese.

[12] C. Hou and X. Li, "Stability principle of big and small structures of rock surrounding roadway driven along goaf in fully mechanized top coal caving face," Journal of China Coal Society, vol. 26, no. 1, pp. 1-7, 2001, in Chinese.

[13] Z. Cao and Y. Zhou, "Research on coal pillar width in roadway driving along goaf based on the stability of key block," CMCComputers Materials \& Continua, vol. 48, no. 2, pp. 77-90, 2015.

[14] R. Wu, Q. Y. He, J. Oh, Z. C. Li, and C. G. Zhang, "A new gobside entry layout method for two-entry longwall systems," Energies, vol. 11, no. 8, p. 2084, 2018.

[15] B. W. Wu, X. Y. Wang, J. B. Bai, W. D. Wu, X. X. Zhu, and G. D. Li, "Study on crack evolution mechanism of roadside backfill body in gob-side entry retaining based on UDEC trigon model," Rock Mechanics and Rock Engineering, vol. 52, no. 9, pp. 3385-3399, 2019.

[16] C. C. Qi and A. Fourie, "Cemented paste backfill for mineral tailings management: review and future perspectives," Minerals Engineering, vol. 144, Article ID 106025, 2019.

[17] W. F. Li, J. B. Bai, S. Peng, X. Y. Wang, and Y. Xu, "Numerical modeling for yield pillar design: a case study," Rock Mechanics and Rock Engineering, vol. 48, no. 1, pp. 305-318, 2015.

[18] J. Y. Fan, H. P. Xie, C. Jie et al., "Preliminary feasibility analysis of a hybrid pumped-hydro energy storage system using abandoned coal mine goafs," Applied Energy, vol. 258, Article ID 114007, 2020.

[19] B. Zhang, Deformation mechanisms and strengthen technology for the gob-side roadway surrounding rock under mining influence in top coal caving face with thick layer, Ph.D. thesis. China University of Mining and Technology, Xuzhou, China, 2015, in Chinese.

[20] X. Xu, J. Li, S. Tian, Z. Liu, and Y. Li, "Deformation analysis and neutral plane stability control technology of small coal pillar with gob-side entry," Journal of Mining and Safety Engineering, vol. 33, no. 3, pp. 481-485, 2016, in Chinese.

[21] H. Liu, X. Wu, Z. Hao, X. Zhao, and X. Guo, "Evolution law and stability control of plastic zones of retained entry of working face with double roadways layout," Journal of Mining and Safety Engineering, vol. 32, no. 4, pp. 689-697, 2017, in Chinese.

[22] P. Yang, X.-Z. Hua, Y.-F. Li, Q.-J. Liu, and S. Yang, "Backfill horizontal stability analysis of gob-side entry retaining with compound roof in deep mine," Rock and Soil Mechanics, vol. 39, no. S1, pp. 405-411, 2018, in Chinese.

[23] G. C. Zhang, Asymmetric failure mechanism and regulation system of gob-side entry roof with fully-mechanized caving mining and a loose and weak coal pillar, Ph.D. thesis, China University of Mining and Technology, Xuzhou, Beijing, China, 2017, in Chinese.

[24] M. G. Qian, X. X. Miao, J. L. Xu et al., Key Strata Theory in Ground Control, China University of Mining and Technology, Xuzhou, China, 2000.

[25] H. L. Liu, T. H. Yang, P. H. Zhang et al., "O-X failure pattern of roof and strata-pressure behavior under complex geological conditions," Journal of Mining and Safety Engineering, vol. 32, no. 5, pp. 439-445, 2015, in Chinese.

[26] Itasca Consulting Group Inc., FLAC a Fast Lagrangian Analysis of Continua, Itasca Consulting Group Inc., Minneapolis, MN, USA, 2012.

[27] G. Esterhuizen, "Jointing effects on pillar strength," in Proceeding of 19th International Conference on Ground Control in Mining, West Virginia University, Morgantown, WV, USA, pp. 286-290, 2000.

[28] J. Lu, R. Anil, M. Khaled, and P. Syd, "Effects of rock/coal interface property on coal pillar strength," in Proceeding of 27th International Conference on Ground Control in Mining, West Virginia University, Morgantown, WV, USA, pp. 262267, January 2008.

[29] K. A. Perry, K. F. Unrug, K. W. Harris, and M. J. Raffaldi, "Influence of roof/floor interface on coal pillar performance," in Proceeding of 32nd International Conference on Ground Control in Mining, West Virginia University, Morgantown, WV, USA, pp. 1-7, July 2013.

[30] W.-1. Shen, J.-b. Bai, W.-f. Li, and X.-y. Wang, "Prediction of relative displacement for entry roof with weak plane under the effect of mining abutment stress," Tunnelling and Underground Space Technology, vol. 71, pp. 309-317, 2018.

[31] D. Ma, H. Y. Duan, X. B. Li et al., "Effects of seepage-induced erosion on nonlinear hydraulic properties of broken red sandstones," Tunnelling and Underground Space Technology, vol. 91, Article ID 102993, 2019.

[32] M. Shabanimashcool and C. C. Li, "Numerical modelling of longwall mining and stability analysis of the gates in a coal mine," International Journal of Rock Mechanics and Mining Sciences, vol. 51, pp. 24-34, 2012.

[33] Y. B. Gao, D. Q. Liu, X. Y. Zhang, and M. C. He, “Analysis and optimization of entry stability in underground longwall mining," Sustainability, vol. 9, no. 11, p. 2079, 2017.

[34] H. Basarir, I. F. Oge, and O. Aydin, "Prediction of the stresses around main and tailgates during top coal caving by $3 \mathrm{D}$ numerical analysis," International Journal of Rock Mechanics and Mining Sciences, vol. 76, pp. 88-97, 2015.

[35] Z. Zhou, X. Cai, D. Ma et al., "Water saturation effects on dynamic fracture behavior of sandstone," International Journal of Rock Mechanics and Mining Sciences, vol. 114, pp. 46-61, 2019.

[36] D. Ma, J. J. Wang, X. Cai et al., "Effects of height/diameter ratio on failure and damage properties of granite under coupled bending and splitting deformation," Engineering Fracture Mechanics, vol. 220, Article ID 106640, 2019.

[37] H. Yavuz and R. J. Fowell, "FDM prediction of a yield pillar performance in conjunction with a field trial," in Proceeding of 
20th International Conference on Ground Control in Mining, West Virginia University, Morgantown, WV, USA, pp. 78-85, August 2001.

[38] M. Salamon, "Mechanism of caving in longwall coal mining," in Rock Mechanics Contributions and Challenges: Proceedings of the 31st US Symposium of Rock Mechanics, pp. 161-168, Golden, CO, USA, June 1990.

[39] S. S. Peng, "Longwall mining," in Advances in Coal Mine Ground Control, pp. 46-53, Peng S. S. Publisher, Morgantown, WV, USA, 2nd edition, 2006.

[40] S. Badr, A. Schissler, M. Salamon, and U. Ozbay, "Numerical modeling of yielding chain pillars in longwall mines," in NARMS-TAC: Mining and Tunnelling Innovation and Opportunity, R. Hammahetal, Ed., pp. 99-106, University of Toronto, Toronto, Canada, 2002.

[41] B. G. D. Smart and S. M. Haley, "Further development of the roof strata tilt concept for pack design and the estimation of stress development in a caved waste," Mining Science and Technology, vol. 5, no. 2, pp. 121-130, 1987.

[42] B. N. Whittaker and R. N. Singh, "Stability of longwall mining gate in relation to rib pillar size," International Journal of Rock Mechanics and Mining Science \& Geomechanics Abstracts, vol. 18, no. 4, pp. 331-334, 1981.

[43] H. Yavuz, "An estimation method for cover pressure re-establishment distance and pressure distribution in the goaf of longwall coal mines," International Journal of Rock Mechanics and Mining Sciences, vol. 41, no. 2, pp. 193-205, 2004. 